\title{
KEABSAHAN PINJAM MEMINJAM UANG SECARA LISAN DALAM PERSPEKTIF HUKUM PERDATA
}

\author{
Oleh : \\ Selamat Lumban Gaol \\ Dosen Tetap Fakultas Hukum Universitas Dirgantara Marsekal Suryadarma, aktif di LKBH Unsurya, \\ anggota Asosiasi Dosen Indonesia (ADI) dan anggota Perancang dan Ahli Hukum Kontrak Indonesia (PAHKI). \\ Email : selamatlumbangaol@gmail.com
}

\begin{abstract}
Abstrak
Suatu pinjam meminjam uang pada awalnya diawali dengan hubungan yang baik dan harmonis serta sama-sama percaya, akan tetapi seiring berjalanya waktu terjadi perselisihan, kemudian dipertanyakan apakah pinjam meminjam secara lisan terdahulu yang mereka lakukan itu sah dan mengikat secara hukum bagi mereka. Untuk itu menarik dan perlu diteliti bagaimanakah pengaturan hukum pinjam peminjan uang dan apakah pinjam meminjam uang secara lisan sah dan mengikat menurut hukum? Untuk menjawab persoalan tersebut dalam penelitian ini digunakan metode penelitian hukum normatif (yuridis normatif) dengan menggunakan data sekunder dan pendekatan Undang-Undang (statute approach). Perjanjian pinjam meminjam uang merupakan bentuk khusus dari perjanjian pinjam meminjam yang diatur dalam Pasal 1754 sampai dengan Pasal 1769, bab XII Buku III KUH Perdata yang bersifat mengatur (aanvullendrecht), dan tidak norma yang mengharuskannya dibuat secara tertulis dan suatu perjanjian pinjam meminjam uang secara lisan adalah sah dan berharga serta memiliki kekuatan hukum yang mengikat, apabila didahului adanya persesuaian kehendak antara pihak yang meminjamkan uang (kreditor) dan pihak yang meminjam (debitor), serta tidak bertentangan dengan atau tidak dilarang oleh Undang-Undang, kesusilaan yang baik, dan ketertiban umum. Untuk itu perlu adanya Undang-Undang tentang Perikatan termasuk di dalamnya mengatur hal-hal berkaitan tentang pinjam meminjam uang dan perlu dilakukan sinkronisasi dan harmonisasi Undang-Undang yang berkaitan dengan pinjam meminjam uang.
\end{abstract}

Kata Kunci : Pinjam Meminjam, Uang, Lisan.

\section{PENDAHULUAN}

\section{A. Latar Belakang Permasalahan}

Dalam interaksi kehidupan seharihari, jamak terdengar antara seorang dengan seorang lainnya berbicara "mana buktinya aku punya hutang sama kamu," atau "sejak kapan aku punya kewajiban melakukan pembayran kepadamu, mana hitam diatas putih di kertas materai atau segelnya."

Mungkin dialog singkat diatas pada awalnya diawali dengan hubungan yang baik dan harmonis serta sama-sama percaya, akan tetapi seiring berjalanya waktu terjadi perselisihan. Dialog singkat tersebut dalam perspektif hukum perdata termasuk ke dalam 2 (dua) topik hukum yaitu pertama adanya hubungan hukum pinjam meminjam uang secara lisan dan kedua berkaitan dengan pembuktian setelah adanya sengketa.

Keabsahan suatu pinjam meminjam uang bukanlah terletak cara atau bentuk pembuatannya, apakah pinjam meminjam tersebut dibuat secara lisan atau tertulis atau tanda pernyataan, hal ini berkaitan dengan masalah pembuktian manakala terjadi perselisihan.

Suatu pinjam meminjam ${ }^{1}$ termasuk pinjam meminjam uang meskipun

${ }^{1}$ Pasal $1754 \mathrm{KUH}$ Perdata, berbunyi "Pinjam Meminjam ialah perjanjian dengan mana pihak yang satu memberikan kepada pihak yang lain suatu jumlah tertentu barang-barang yang menghabis karena pemakaian, dengan syarat bahwa pihak yang 
dilakukan secara lisan tetap sah dan mengikat apabila telah memenuhi syarat sahnya suatu perjanjian yang diatur dalam Kitab Undang-Undang Hukum Perdata (KUH Perdata), baik syarat subjektif maupun syarat objektif sahnya suatu perjanjian.

Pinjam meminjam uang merupakan dan sebagai suatu perjanjian riil, dimana persetujuan peminjaman uang baru mengikat setelah uang yang diserahkan itu diterima oleh peminjam, dan uang yang diterima oleh peminjam tersebut langsung menjadi miliknya si peminjam, sehingga bila hilang atau musnah menjadi tanggungannya si peminjam. ${ }^{2}$

Dari uraian diatas timbul suatu kegelisahan akademik berkenaan dengan pengaturan hukum Perjanjian Pinjam Meminjam Uang Secara Lisan Dalam Perspektif Hukum Perdata.

Berdasarkan latar belakang masalah tersebut, peneliti melakukan penelitian dengan judul "Keabsahan Pinjam Meminjam Uang Secara Lisan Dalam Perspektif Hukum Perdata."

\section{B. Rumusan Masalah}

Bertolak dari uraian latar belakang permasalahan tersebut, dapat dirumuskan permasalahan yang akan dikaji dalam penelitian ini dibatasi pada pokoknya sebagai berikut:

1. Bagaimanakah pengaturan hukum pinjam peminjan uang?

2. Apakah pinjam meminjam uang secara lisan sah dan mengikat menurut hukum?.

\section{Tujuan dan Kegunaan}

Secara teoritis penelitian ini diharapkan dapat mengembangkan ilmu pengetahuan hukum pada umumnya, khususnya hukum perdata terkait dengan pinjam meminjam uang. Kemudian

belakangan ini akan mengembalikan sejumlah yang sama dari macam dan keadaan yang sama pula."

${ }^{2}$ Pasal 1755 KUH Perdata, berbunyi "Berdasarkan perjanjian pinjam meminjam ini, pihak yang menerima pinjaman menjadi pemilik barang yang dipinjam, dan jika barang itu musnah, dengan cara bagaimanapun, maka kemusnahan itu adalah atas tanggungannya." diharapkan juga dapat digunakan sebagai referensi yang dapat ikut menunjang ilmu pengetahuan khususnya ilmu pengetahuan hukum perdata Indonesia termasuk di dalamnya hukum kontrak, hukum pembuktian. Selanjutnya penelitian ini diharapkan juga dapat berguna secara praktis, yaitu menjadi pegangan dan pedoman bagi praktisi hukum dalam menangani penyelsaian sengketa pinjam meminjam uang secara lisan. Penelitian ini juga diharapkan dapat berguna bagi kalangan masyarakat luas ketika hendak mengajukan gugatan ke Pengadilan atas sengketa pinjam meminjam uang secara lisan.

\section{Studi Pustaka}

1. Tinjuan Singkat Tentang Perjanjian Hubungan antara subjek hukum dengan subjek hukum lainnya dan hubungan antar subjek hukum dengan benda yang menimbulkan hak dan kewajiban yang diatur oleh hukum disebut hubungan hukum. ${ }^{3}$

Dari pengertian hubungan hukum yang dikemukakan oleh para ahli hukum, Purnadi Purbacaraka dan Soerjono Soekanto, ${ }^{4}$ Mochtar Kusumaatmadja dan B. Arief Sidharta, ${ }^{5}$ Dudu Duswara

${ }^{3}$ Muhamad Erwin dan H. Firman Freddy Busroh, Pengantar Ilmu Hukum, Cet. 1, (Bandung: PT Refika Aditama, 2012), hlm. 56

${ }^{4}$ Purnadi Purbacaraka dan Soerjono Soekanto menyatakan bahwa "hubungan hukum (rechtsbetrekking) merupakan hubungan-hubungan dalam hukum, sebagai ikatan hak dan kewajiban antar subjek hukum." Lihat Purnadi Purbacaraka dan Soerjono Soekanto, Sendi-sendi Ilmu Hukum Dan Tata Hukum, (Bandung: PT Alumni, 1979), hlm. 49

${ }^{5}$ Mochtar Kusumaatmadja dan B. Arief Sidharta menyatakan bahwa "hubungan hukum adalah hubungan antara dua atau lebih pihak yang diatur oleh kaidah hukum dengan menetapkan akibat-akibat hukum tertentu kepada para pihak dalam hubungan tersebut." Lihat Mochtar Kusumaatmadja dan B. Arief Sidharta, Pengantar Ilmu Hukum Buku I : Suatu Pengenalan Pertama Ruang Lingkup Berlakunya Ilmu Hukum, (Bandung: Alumni, 2000), hlm. 80 
Machmudin, ${ }^{6}$

Wignjodipoero, ${ }^{7}$ tersebut dapat disimpulkan bahwa dalam suatu hubungan hukum tersebut terdapat ikatan hak dan kewajiban para subjek hukum. Salah satu contoh hubungan hukum adalah perikatan (verbintenis) ${ }^{8}$ diatur dalam buku III KUH Perdata, yang terdiri dari 632 Pasal (Pasal 1233 sampai dengan Pasal 1864) dan 18 Bab.

\section{Perikatan (verbintenis) dapat} bersumber / lahir dari Perjanjian (overeenkomst) $^{9}$ ataupun UndangUndang. ${ }^{10}$ Dengan demikian, Perjanjian (overeenkomst) merupakan salah satu sumber dari perikatan (verbintenis).

${ }^{6}$ Dudu Duswara Machmudin menyatakan bahwa "HUBUNGAN HUKUM (rechtsbetrekking) adalah suatu hubungan diantara para subjek hukum yang diatur oleh hukum. Dalam setiap hubungan hukum selalu terdapat hak dan kewajiban." Lihat Dudu Duswara Machmudin, Pengantar Ilmu Hukum: Sebuah Sketsa, (Bandung: Refika Aditama, 2001), hlm. 49

${ }^{7}$ Soerojo Wignjodipoero menyatakan bahwa "hubungan hukum ialah suatu hubungan antara dua subjek hukum atau lebih, dimana hak dan kewajiban di satu pihak berhadapan dengan hak dan kewajiban di pihak lain. adanya hubungan hukum harus memenuhi syarat-syarat yaitu adanya dasar hukumnya dan timbulnya peristiwa hukum ataupun perbuatan hukum." Lihat Soerojo Wignjodipoero, Pengantar Ilmu Hukum, (Jakarta: CV. Haji Masagung, 1989), hlm. 38 - 39

${ }^{8}$ Istilah verbintenis dalam buku III KUH Perdata tersebut ternyata diterjemahkan berbeda dalam kepustakaan hukum Indonesia oleh para ahli hukum. Walaupun pada umumnya digunakan istilah perikatan untuk menterjemahkan verbintenis. Ada yang menterjemahkan perutangan (Sri Soedewi Masjchoen Sofwan), perikatan (Subekti, Mariam Darus Badrulzaman, J. Satrio). Terjemahan verbintenis dengan perutangan, karena ada utang prestasi. Sedangkan dari segi tata bahasa verbintenis berasal dari kata kerja verbinden yang berarti mengikat, jadi verbintenis menunjuk kepada adanya ikatan atau hubungan, sehingga verbintenis diterjemahkan dengan perikatan.

${ }^{9}$ Padanan kata Perjanjian dalam bahasa Belanda Overeenkomst, dalam bahasa Asing Lainnya, Agreement, Pact, covenant, contract, appointment, engangement. Dalam perspektif hukum perdata padanan kata Perjanjian adalah Persetujuan atau Kontrak.

${ }^{10} \mathrm{KUH}$ Perdata Pasal 1233 "Tiap-tiap perikatan dilahirkan baik karena persetujuan, baik karena Undang-undang."
Dalam perspektif sistematika

buku III KUH Perdata, pengaturan Perjanjian terdapat dalam 18 (delapan belas) bab yaitu bab kedua, ${ }^{11}$ bab keempat, ${ }^{12}$ bab kelima, ${ }^{13}$ bab keenam, ${ }^{14}$

${ }^{11}$ Perjanjian sebagai sumber Perikatan diatur dalam bab kedua buku III KUH Perdata (Pasal 1313 sampai dengan Pasal 1351).

${ }^{12}$ HAPUSnya Perjanjian diatur dalam bab Keempat buku III KUH Perdata, sebanyak 65 Pasal (Pasal 1381 sampai dengan Pasal 1456). Pasal 1381 pada pokoknya mengatur bahwa Perikatan-perikatan HAPUS karena 10 hal yaitu 1) Pembayaran, diatur dalam sebanyak 22 Pasal (Pasal 1382 sampai dengan Pasal 1403); 2) Penawaran Pembayaran Tunai diikuti dengan Penyimpanan atau Penitipan, diatur dalam sebanyak 9 (sembila) Pasal (Pasal 1404 sampai dengan Pasal 1412); 3) Pembaharuan Utang, diatur dalam sebanyak 12 (dua belas) Pasal (Pasal 1413 sampai dengan Pasal 1424); 4) Perjumpaan Utang atau Kompensasi, diatur dalam sebanyak 11 (sebelas) Pasal (Pasal 1425 sampai dengan Pasal 1435); 5) percampuran Utang, diatur dalam sebanyak 2 (dua) Pasal (Pasal 1436 dan Pasal 1437); 6) pembebasan utang, diatur dalam sebanyak 6 (enam) Pasal (Pasal 1438 sampai dengan Pasal 1443); 7) musnahnya Barang yang terutang, diatur dalam sebanyak 2 (dua) Pasal (Pasal 1444 dan Pasal 1445); 8) kebatalan atau pembatalan, diatur dalam sebanyak 11 (sebelas) Pasal (Pasal 1446 sampai dengan Pasal 1456); 9) berlakunya suatu Syarat Batal, yang diatur dalam Bab Kesatu Buku III ini, diatur dalam sebanyak dan; 10) daluwarsa (lewatnya waktu) yang diatur dalam Buku IV KUH Perdata.

${ }^{13}$ Jenis-jenis Perjanjian bernama (nominaat) diatur dalam bab Kelima buku III KUH Perdata (Pasal 1457 sampai dengan Pasal 1864) ada 15 (lima belas) Perjanjian, yang diatur dalam 1) Bab V Jual Beli; 2) Bab VI Tukar Menukar; 3) Bab VII Sewa Menyewa; 4) Bab VIII A Perjanjian-perjanjian Untuk Melakukan Pekerjaan; 5) Bab VIII Persekutuan; 6) Bab IX Perkumpulan; 7) Bab X Hibah; 8) Bab XI Penitipan Barang; 9) Bab XII Pinjam Pakai; 10) Bab XIII Pinjam Meminjam; 11) Bab XIV Bunga Tetap Atau Bunga Abadi; 12) Bab XV Perjanjian Untung-untungan; 13) Bab XVI Pemberian Kuasa; 14) Bab XVII Penanggungan Utang; 15) Bab XVIII Perdamaian.

Bab V Jual Beli, terdiri dari 83 (delapan puluh tiga) Pasal (Pasal 1457 sampai dengan Pasal 1540) dan 5 (lima) bagian, yaitu 1) Bagian Kesatu KetentuanKetentuan Umum, terdiri dari 16 (enam belas) Pasal (Pasal 1457 sampai dengan Pasal 1472), 2) Bagian Kedua Kewajiban-Kewajiban Penjual, terdiri dari 40 (empat puluh) Pasal (Pasal 1473 sampai dengan Pasal 1512), 3) Bagian Ketiga Kewajiban Pembeli, terdiri dari 6 (enam) Pasal (Pasal 1513 sampai dengan Pasal 1518), 4) Bagian Keempat Hak Membeli Kembali, terdiri dari 14 (empat belas) Pasal (Pasal 1519 sampai dengan Pasal 1532), 5) Bagian Kelima Ketentuan-Ketentuan Khusus Jual Beli Piutang Dan Lain-lain Hak Tak Bertubuh, terdiri dari 8 (delapan) Pasal (Pasal 1533 sampai dengan Pasal 1540). 


bab ketujuh, ${ }^{15}$ bab ke delapan $A,{ }^{16}$ bab
kedelapan ${ }^{17}$ bab kesembilan, ${ }^{18}$ bab
kesepuluh, ${ }^{19}$ bab kesebelas, ${ }^{20}$ bab kedua

${ }^{14} \mathrm{Bab}$ VI Tukar Menukar, terdiri dari 6 (enam) Pasal (Pasal 1541 sampai dengan Pasal 1546).

${ }^{15}$ Bab VII Sewa Menyewa, terdiri dari 54 (lima puluh empat) Pasal (Pasal 1547 sampai dengan Pasal 1600) dan 4 (empat) bagian, yaitu 1) Bagian Kesatu Ketentuan Umum, terdiri dari 3 (tiga) Pasal (Pasal 1547 sampai dengan Pasal 1549); 2) Bagian Kedua Aturanaturan Yang Sama Berlaku Terhadap Penyewaan Rumah Dan Penyewaan Tanah, terdiri dari 31 (tiga puluh satu) Pasal (Pasal 1550 sampai dengan Pasal 1580); 3) Bagian Ketiga Aturan-aturan Yang Khusus Berlaku Bagi Sewa Rumah Dan Perabot Rumah, terdiri dari 7 (tujuh) Pasal (Pasal 1581 sampai dengan Pasal 1587); 4) Bagian Keempat Aturan-aturan Yang Khusus Berlaku Bagi Sewa Tanah, terdiri dari 13 (tiga belas) Pasal (Pasal 1588 sampai dengan Pasal 1600).

${ }^{16} \mathrm{Bab}$ VIII A Perjanjian-perjanjian Untuk Melakukan Pekerjaan, tediri dari 18 (delapan belas) Pasal (Pasal 1601 sampai dengan Pasal 1617) dan 6 (enam) bagian, yaitu 1) Bagian Kesatu Ketentuanketentuan Umum, terdiri dari 4 (empat) Pasal (Pasal 1601 sampai dengan Pasal 1601 c); 2) Bagian Kedua Perjanjian Perburuhan Umumnya, terdiri dari 22 (dua puluh dua) Pasal (Pasal 1601 d sampai dengan Pasal 1601 y); Bagian Ketiga Kewajiban Majikan, terdiri dari 27 (dua puluh tujuh) Pasal (Pasal 1602 sampai dengan Pasal 1602 z); 4) Bagian Keempat Kewajiban Buruh, terdiri dari 5 (lima) Pasal (Pasal 1603 sampai dengan Pasal 1603 d); 5) Bagian Kelima Bermacam-macam cara Berakhirnya Hubungan Kerja, Yang Diterbitkan Dari Perjanjian, terdiri dari 22 (dua puluh dua) Pasal (Pasal 1603 e sampai dengan Pasal 1603 z); 6) Bagian Keenam Pemborongan Pekerjaan, terdiri dari 14 (empat belas) Pasal (Pasal 1604 sampai dengan Pasal 1617).

${ }^{17}$ Bab VIII Persekutuan, terdiri dari 35 (tiga puluh lima) Pasal (Pasal 1618 sampai dengan Pasal 1652) dan 4 (empat) bagian yaitu 1) Bagian Kesatu Ketentuan-ketentuan Umum, terdiri dari 23 (dua puluh tiga) Pasal (Pasal 1618 sampai dengan Pasal 1623); 2) Bagian Kedua Perikatan-perikatan Antara Para Sekutu, terdiri dari 18 (delapan belas) Pasal (Pasal 1624 d sampai dengan Pasal 1641); 3) Bagian Ketiga Perikatanperikatan Para Sekutu Terhadap Orang-orang Ketiga, terdiri dari 4 (empat) Pasal (Pasal 1642 sampai dengan Pasal 1645); 4) Bagian Keempat Bermacam-macam Cara Berakhirnya Persekutuan, terdiri dari 7 (tujuh) Pasal (Pasal 1646 sampai dengan Pasal 1652).

${ }^{18} \mathrm{Bab}$ IX Perkumpulan, terdiri dari 7 (tujuh) Pasal (Pasal 1653 sampai dengan Pasal 1665).

${ }^{19} \mathrm{Bab} \times \mathrm{X}$ Hibah, terdiri dari 28 (dua puluh delapan) Pasal (Pasal 1666 sampai dengan Pasal 1693) dan 4 (empat) bagian yaitu 1) Bagian Kesatu Ketentuanketentuan Umum, terdiri dari 10 (sepuluh) Pasal (Pasal 1666 sampai dengan Pasal 1675); 2) Bagian Kedua Kecakapan Untik Memberikan Sesuatu Sebagai Hibah, dan Untuk Menikmati Keuntungan Dari Suatu Hibah, terdiri dari 6 (enam) Pasal (Pasal 1676 d sampai dengan Pasal 1681); 3) Bagian Ketiga Cara Menghibahkan Sesuatu, terdiri dari 6 (enam) Pasal (Pasal 1682 sampai dengan Pasal 1687); 4) Bagian Keempat Penarikan belas, ${ }^{21}$ bab ketiga belas, ${ }^{22}$ bab keempat

belas, ${ }^{23}$ bab kelima belas, ${ }^{24}$ bab kenam

belas, ${ }^{25}$ bab ketujuh belas, ${ }^{26}$ bab kedelapan belas. ${ }^{27}$

Kembali Dan Penghapusan Hibah, terdiri dari 6 (enam) Pasal (Pasal 1688 sampai dengan Pasal 1693).

${ }^{20}$ Bab XI Penitipan Barang, terdiri dari 46 (empat puluh enam) Pasal (Pasal 1694 sampai dengan Pasal 1739) dan 3 (tiga) bagian yaitu 1) Bagian Kesatu Penitipan Barang Pada Umum, Dan Berbagai Macam Penitipan, terdiri dari 2 (dua) Pasal (Pasal 1694 sampai dengan Pasal 1695); 2) Bagian Kedua Penitipan Barang Yang Sejati, terdiri dari 34 (tiga puluh empay) Pasal (Pasal 1696 sampai dengan Pasal 1729); 3) Bagian Ketiga Cara Menghibahkan Sesuatu, terdiri dari 10 (sepuluh) Pasal (Pasal 1730 sampai dengan Pasal 1739).

${ }^{21}$ Bab XII Pinjam Pakai, terdiri dari 14 (empat belas) Pasal (Pasal 1740 sampai dengan Pasal 1753) dan 3 (tiga) bagian yaitu 1) Bagian Kesatu Ketentuanketentuan Umum, terdiri dari 4 (empat) Pasal (Pasal 1740 sampai dengan Pasal 1743); 2) Bagian Kedua Kewajiban-kewajiban Seorang Yang Menerima Pinjaman Sesuatu, terdiri dari 6 (enam) Pasal (Pasal 1744 sampai dengan Pasal 1749); 3) Bagian Ketiga Cara Menghibahkan Sesuatu, terdiri dari 4 (empat) Pasal (Pasal 1750 sampai dengan Pasal 1753)

${ }^{22}$ Bab XIII Pinjam Meminjam, terdiri dari 16 (enam belas) Pasal (Pasal 1754 sampai dengan Pasal 1769) dan 4 (empat) bagian yaitu 1) Bagian Kesatu Ketentuan-ketentuan Umum, terdiri dari 5 (lima) Pasal (Pasal 1754 sampai dengan Pasal 1758); 2) Bagian Kedua Kewajiban-kewajiban Orang Yang Meminjamkan, terdiri dari 4 (empat) Pasal (Pasal 1759 d sampai dengan Pasal 1762); 3) Bagian Ketiga Kewajiban-kewajiban Si Peminjam, terdiri dari 2 (dua) Pasal (Pasal 1763 sampai dengan Pasal 1764); 4) Bagian Keempat Meminjam Dengan Bunga, terdiri dari 5 (lima) Pasal (Pasal 1765 sampai dengan Pasal 1769)

${ }^{23}$ Bab XIV Bunga Tetap Atau Bunga Abadi, terdiri dari 4 (empat) Pasal (Pasal 1770 sampai dengan Pasal 1773)

${ }^{24} \mathrm{Bab}$ XV Perjanjian Untung-untungan, terdiri dari 18 (delapan belas) Pasal (Pasal 1774 sampai dengan Pasal 1791) dan 3 (tiga) bagian yaitu 1) Bagian Kesatu Ketentuan Umum, terdiri dari 1 (satu) Pasal (Pasal 1774); 2) Bagian Kedua Perjanjian Bunga Cagak Hidup Dan Akibat-akibatnya, terdiri dari 13 (tiga belas) Pasal (Pasal 1775 sampai dengan Pasal 1787); 3) Bagian Ketiga Perjudian Dan Pertaruhan, terdiri dari 4 (empat) Pasal (Pasal 1788 sampai dengan Pasal 1791).

${ }^{25}$ Bab XVI Pemberian Kuasa, terdiri dari 28 (dua puluh delapan) Pasal (Pasal 1792 sampai dengan Pasal 1819) dan 4 (empat) bagian yaitu 1) Bagian Kesatu Sifat Pemberian Kuasa, terdiri dari 8 (delapan) Pasal (Pasal 1792 sampai dengan Pasal 1799); 2) Bagian Kedua Kewajiban-kewajiban Si Kuasa, terdiri dari 7 (tujuh) Pasal (Pasal 1800 d sampai dengan Pasal 1806); 3) Bagian Ketiga Kewajiban-kewajiban Si Pemberi Kuasa, terdiri dari 6 (enam) Pasal (Pasal 1807 sampai dengan Pasal 1812); 4) Bagian Keempat Bermacammacam Cara Berakhirnya Kuasa, terdiri dari 7 (tujuh) Pasal (Pasal 1813 sampai dengan Pasal 1819). 
Sedangkan Perikatan yang bersumber atau dilahirkan karena / dari Undang-Undang diatur dalam Bab Ketiga buku III KUH Perdata dengan judul Perikatan-Perikatan Yang Dilahirkan Demi Undang-Undang, terdiri dari 29 (dua puluh sembilan) Pasal (Pasal 1352 sampai dengan Pasal 1380).

Perjanjian dapat dibuat secara lisan maupun tertulis. Apabila perjanjian tersebut dibuat secara tidak tertulis atau lisan dinamakan persetujuan atau perjanjian, sedangkan apabila perjanjian tersebut dibuat secara tertulis dinamakan kontrak. ${ }^{28}$

Suatu perjanjian harus memenuhi dan memperhatikan asas-asas hukum perjanjian, selain syarat-syarat sahnya suatu perjanjian yang diatur dalam KUH Perdata.

Perjanjian adalah suatu PERBUATAN dengan mana satu orang atau lebih MENGIKATKAN DIRInya terhadap satu orang lain atau lebih. (vide Pasal 1313 KUH Perdata). Kata PERBUATAN dalam Pasal 1313 KUH Perdata tersebut, harus dibaca atau dimaknai sebagai PERBUATAN

${ }^{26}$ Bab XVII Penanggungan Utang, terdiri dari 31 (tiga puluh satu) Pasal (Pasal 1820 sampai dengan Pasal 1850) dan 4 (empat) bagian yaitu 1) Bagian Kesatu Sifat Penanggungan, terdiri dari 11 (sebelas) Pasal (Pasal 1820 sampai dengan Pasal 1830); 2) Bagian Kedua Akibat-akibat Penanggungan Antara Si Berutang Dengan Si Penanggung, terdiri dari 8 (delapan) Pasal (Pasal 1831 d sampai dengan Pasal 1838); 3) Bagian Ketiga Akibatakibat Penanggungan Antara Si Berutang Dan Si Penanggung, Dan Antara Penanggung Sendiri, terdiri dari 6 (enam) Pasal (Pasal 1839 sampai dengan Pasal 1844); 4) Bagian Keempat Hapusnya Penanggungan Utang, terdiri dari 6 (enam) Pasal (Pasal 1845 sampai dengan Pasal 1850).

${ }^{27}$ Bab XVIII Perdamaian, terdiri dari 14 (empat belas) Pasal (Pasal 1851 sampai dengan Pasal 1864)

${ }^{28}$ Perkataan kontrak, lebih sempit karena ditujukan kepada perjanjian atau persetujuan yang tertulis. Subekti (a), Hukum Perjanjian, Cet. 23 (Jakarta: Intermasa, 2010), hlm. 1.
HUKUM $^{29}$ atau TINDAKAN HUKUM, karena kata PERBUATAN dalam rumusan Pasal 1313 tersebut SANGAT LUAS, sehingga apabila kata PERBUATAN dalam rumusan Pasal 1313 tersebut dimaknai PERBUATAN / TINDAKAN HUKUM memberikan makna AKIBAT HUKUM $^{30}$ dari PERBUATAN / TINDAKAN HUKUM tersebut DIKEHENDAKI atau DIANGGAP DIKEHENDAKI Para Pihak yang membuat Perjanjian, dan juga dengan sendirinya telah tersimpul adanya SEPAKAT, yang merupakan CIRI daripada Perjanjian, yang tidak mungkin ada pada Perbuatan Melawan Hukum (onrechtmatige daad) dan tindakan Pengurusan harta/kepentingan pihak lain tanpa diminta (zaakwarneming). ${ }^{31}$

Kata MENGIKATKAN dalam rumusan Pasal 1313 KUH Perdata merupakan kata kerja yang sifatnya hanya datang dari satu pihak saja, tidak dari kedua pihak. ${ }^{32}$ Sedangkan maksud perjanjian itu para pihak saling mengikatkan diri, sehingga tampak kekurangannya yang seharusnya ditambah dengan rumusan SALING MENGIKATKAN DIRI. ${ }^{33}$

Asas-asas hukum $^{34}$ dalam perjanjian atau disebut juga sebagai

${ }^{29}$ R. M. Suryodiningrat, Azas-Azas Hukum Perikatan, Ed. 2, (Bandung: Tarsito, 1985), hlm. 72-75.

${ }^{30}$ PERBUATAN HUKUM yaitu PERBUATAN yang menimbulkan AKIBAT HUKUM. Lihat Purwahid Patrik, Dasar-Dasar Hukum Perikatan (Perikatan Yang Lahir Dari Perjanjian Dan UndangUndang), Cet. 1, (Bandung: CV Mandar Maju, 1994), hlm. 46.

${ }^{31}$ J. Satrio (a), Hukum Perikatan: Perikatan Yang Lahir Dari Perjanjian Buku I, Cet. 1, (Bandung: PT Citra Aditya Bakti, 1995), hlm. 24-27.

${ }^{32}$ Purwahid Patrik, Op.Cit., hlm. 45.

${ }^{33}$ Ibid.

${ }^{34}$ Asas-asas hukum sebagai norma-norma penguji yang fundamental adalah pokok-pokok pikiran yang melandasi sistem hukum yang nyata berfungsi sebagai hukum positif. Herlien Budiono (a), Asas Keseimbangan Bagi Hukum Perjanjian Indonesia (Hukum Perjanjian Berdasarkan Asas-asas Wigati 
asas-asas hukum perjanjian, menurut para ahli masih bersifat variatif, belum ada kesepakatan yang telah baku mengenai jumlah asas-asas hukum dalam hukum perjanjian.

Dari beberapa pendapat ahli, Sudikno Mertokusumo, ${ }^{35}$ Mariam Darus Badrulzaman, ${ }^{36}$ Herlien Budiono, ${ }^{37}$ Ridwan Khairandy, ${ }^{38}$ dapat disimpulkan bahwa asas hukum dalam bidang perjanjian ada 4 (empat) yaitu 1) asas konsensualisme, ${ }^{39}$ 2) asas kekuatan mengikat (pacta sunt

Indonesia), Cet. 1, (Bandung: PT Citra Aditya Bakti, 2006), hlm. 2.

${ }^{35}$ Menurut Sudikno Mertokusumo, ada 3 (tiga) asas hukum perjanjian yaitu asas konsensualisme, asas pacta sunt servanda dan asas kebebasan berkontrak. Lihat Sudikno Mertokusumo (a), Mengenal Hukum Suatu Pengantar, Cet. 2, (Yogyakarta: Liberty, 1999), hlm. 111-112.

${ }^{36}$ Sedangkan menurut Mariam Darus Badrulzaman, ada 10 (sepuluh) asas hukum perjanjian yaitu 1) asas perjanjian yang sah adalah Undang-undang; 2) asas kebebasan berkontrak; 3) asas konsensualisme; 4) asas kepercayaan; 5) asas kekuatan mengikat; 6) asas persamaan hukum; 7) asas keseimbangan; 8) asas kepastian hukum; 9) asas moral, dan; 10) asas kepatutan. Lihat Mariam Darus Badrulzaman, et.al, Kompilasi Hukum Perikatan, Cet. 1, (Bandung: PT Citra Aditya Bakti, 2000), hlm. 82-89.

${ }^{37}$ Sementara itu menurut Herlien Budiono, ada 4 (empat) asas hukum perjanjian yaitu asas konsensualisme, asas kekuatan mengikat, asas kebebasan berkontrak dan asas keseimbangan. Lihat juga Herlien Budiono (b), Ajaran Umum Hukum Perjanjian Dan Penerapannya Di Bidang Kenotariatan, Cet. 1, (Bandung: PT Citra Aditya Bakti, 2009), hlm. 29-34.

${ }^{38}$ Sedangkan menurut Ridwan Khairandy, asas hukum dalam hukum perjanjian itu ada 4 (empat) yang disimpulkan dari ketentuan Pasal 1338 KUH Perdata yaitu asas konsensualisme, asas pacta sunt servanda, asas kebebasan berkontrak, dan asas itikad baik. Lihat pula Ridwan Khairandy, Hukum Kontrak Indonesia dalam Perspektif Perbandingan (Bagian Pertama), Cet. 1, (Yogyakarta: FH UII Press, 2013), hlm. 84

${ }^{39}$ Konsensus berasal dari kata latin "consensus," yang artinya sepakat. Dalam membuat perjanjian diisyaratkan adanya konsensus yaitu para pihak sepakat atau setuju mengenai prestasi yang diperjanjikan. Sepakat adalah persesuaian paham dan kehendak antara para pihak yang membuat kontrak. Lihat Muhammad Syaifuddin, Hukum Kontrak: Memahami Kontrak Dalam Perspektif Filsafat, Teori, Dogmatik, Dan Praktik Hukum (Seri Pengayaan Hukum Perikatan), Cet. 1, (Bandung: PT Mandar Maju, 2012), hlm. 77.

servanda), ${ }^{40}$ 3) asas kebebasan

berkontrak, ${ }^{41}$ dan 4) asas itikad baik (te goede trouw; in good faith). ${ }^{42}$

Syarat Sahnya Suatu Perjanjian diatur dalam Pasal 1320 KUH Perdata, pada pokoknya sebagai berikut:

$\begin{array}{ccc}\text { Pertama } & \text { SEPAKAT } & \text {; } \\ \text { KESEPAKATAN, dalam Pasal } & 1320 \\ \text { KUH Perdata } & \text { tersebut, } & \text { tidak }\end{array}$

${ }^{40}$ Asas pacta sunt servanda ini dikenal juga dengan asas kekuatan mengikatnya suatu perjanjian. Kesepakatan (konsensus) para pihak yang dibuat secara sah menimbulkan kekuatan mengikat perjanjian sebagaimana layaknya Undang-undang (pacta sunt servanda). Lihat Ridwan Khairandy, Op.Cit, hlm. 91. Adagium pacta sunt servanda diakui sebagai aturan yang menempatkan bahwa semua perjanjian yang dibuat secara sah, mengingat kekuatan hukum yang terkandung di dalamnya, dimaksudkan untuk dilaksanakan dan pada akhirnya dapat dipaksakan penataannya. Lihat pula Herlien Budiono (b), Op.Cit, hlm. 31.

${ }^{41}$ Asas kebebasan berkontrak atau asas kebebasan mebuat kontrak dikenal dengan istilah "partij otonomie" atau "freedom of contract" atau "liberty of contract." Lihat Muhammad Syaifuddin, Op.Cit, hlm. 81. Dengan asas kebebasan berkontrak orang dapat menciptakan jenis perjanjian baru yang sebelumnya tidak dikenal di dalam perjanjian bernama dan isinya menyimpang dari nama perjanjian bernama yang diatur oleh Undang-undang, yang dikenal sebagai perjanjian tidak bernama. Lihat juga Ridwan Khairandy, Op.Cit, hlm. 87. Asas kebebasan berkontrak bukan berarti kebebasan berkontrak yang sebebas-bebasnya tanpa batas, melainkan dalam batas tertentu dengan ruang lingkup sebagai berikut a) kebebasan untuk membuat atau tidak membuat perjanjian; b) kebebasan untuk memilih pihak dengan siapa ia ingin membuat perjanjian; c) kebebasan untuk menentukan atau memilih kausa dari perjanjian yang akan dibuatnya; d) kebebasan untuk menentukan objek perjanjian; e) kebebasan untuk menentukan bentuk suatu perjanjian; f) kebebasan untuk menerima atau menyimpangi ketentuan Undang-undang yang bersifat opsional (aanvullendrecht, optional). Lihat pula Sutan Remy Sjahdeini, Kebebasan Berkontrak Dan Perlindungan Yang Seimbang Bagi Para Pihak Dalam Perjanjian Kredit Bank Di Indoensia, Cet. 1, (Jakarta: Institut Bankir Indonesia, 1993), hlm. 47.

${ }^{42}$ Asas itikad baik ini disimpulkan dan tercermin dari ketentuan Pasal 1338 ayat (3) KUH Perdata, yang pada pokoknya menggariskan bahwa setiap perjanjian harus dilaksanakan dengan itikad baik. Secara a contra rio ketentuan Pasal 1338 ayat (3) KUH Perdata a quo dapat juga dimaknai bahwa setiap perjanjian harus dibuat / dirancang pada masa / fase pra kontrak dengan itikad baik juga. Dengan demikian itikad baik dalam hukum kontrak atau hukum perjanjian dapat dimaknai bahwa suatu perjanjian harus dilandasari dengan itikad baik pada saat tahap / fase pra kontrak maupun pada saat pelaksanaan kontrak. 
dijelaskan secara jelas dalam KUH Perdata, yang diatur adalah TIADA SEPAKAT dalam Pasal 1321, 1322, 1324, 1325, 1328 KUH Perdata tersebut secara a contra rio. Pengertian SEPAKAT dilukiskan sebagai PERNYATAAN KEHENDAK yang DISETUJUI (overeenstemende wilsverklaring) antara pihak-pihak yaitu pihak yang menawarkan tawaran (offerte) dan pihak yang menerima tawaran (akseptasi ; acceptatie). ${ }^{43}$ SEPAKAT atau SETUJU atau juga dinamakan PERIZINAN (toestemming) merupakan PERTEMUAN antara dua KEHENDAK (PERSESUAIAN KEHENDAK), dimana KEHENDAK yang satu saling mengisi dengan apa yang dikehendaki pihak lain, sehingga Para Pihak dalam PERJANJIAN yang bersangkutan harus BERSEPAKAT, SETUJU atau SEIA-SEKATA mengenai hal-hal yang pokok dari PERJANJIAN yang diadakan itu, mereka MENGHENDAKI sesuatu yang SAMA secara TIMBAL BALIK, misalnya si Penjual mengingini sejumlah UANG, sedangkan si PEMBELI MENGINGINI sesuatu BARANG. ${ }^{44}$ KESEPAKATAN dalam suatu PERJANJIAN merupakan PERWUJUDAN KEHENDAK dari Para PIHAK dalam PERJANJIAN yang bersangkutan mengenai APA yang Para Pihak KEHENDAKI untuk DILAKSANAKAN / dipenuhi, BAGAIMANA cara MELAKSANAKANnya, KAPAN harus DILAKSANAKAN, dan SIAPA yang harus MELAKSANAKAN diantara Para Pihak dalam Perjanjian

${ }^{43}$ Mariam Darus Badrulzaman, KUH Perdata Buku III: Hukum Perikatan Dengan Penjelasan, Ed. 2, Cet. 3, (Bandung: Alumni, 2011), hlm. 98.

${ }^{44}$ Subekti (a), Loc.Cit, hlm. 17. Lihat juga J. Satrio (a), Op.Cit, hlm. 164-165. yang bersangkutan. ${ }^{45}$ Berdasarkan Pasal 1321, 1322, 1324, 1325, 1328 KUH Perdata, TIADA SEPAKAT karena adanya Kehilafan, PAKSAAN / ANCAMAN (dwang) dan Penipuan.

Kedua KECAKAPAN ; CAKAP, dalam Pasal 1320 KUH Perdata tersebut, tidak dijelaskan secara jelas dalam KUH Perdata, yang diatur adalah TIDAK CAKAP dalam Pasal 1330 KUH Perdata tersebut secara $a$ contra rio.

Ketiga HAL TERTENTU, dalam Pasal 1320 KUH Perdata tersebut, tidak dijelaskan secara jelas dalam KUH Perdata, akan tetapi dari ketentuan Pasal 1332, 1333, 1334 ayat (2) KUH Perdata dapat disimpulkan bahwa OBJEK suatu PERJANJIAN tersebut adalah suatu hal tertentu yang dapat ditentukan berupa BARANG tertentu atau dapat ditentukan. Suatu perjanjian harus mengenai suatu hal tertentu, artinya apa yang diperjanjikan hak-hak dan kewajiban kedua belah pihak jika timbul suatu perselisihan. ${ }^{46}$

Keempat SEBAB yang HALAL atau causa yang HALAL atau causa yang TIDAK DILARANG atau sebab yang TIDAK DILARANG atau SEBAB/KAUSA yang HALAL, dalam Pasal 1320 KUH Perdata tersebut, tidak dijelaskan secara jelas dalam KUH Perdata, yang diatur adalah "suatu SEBAB adalah TERLARANG" dalam Pasal 1337 KUH Perdata tersebut secara a contra rio. Ada PERBEDAAN antara SEBAB/KAUSA dengan MOTIF. MOTIF adalah SEBAB di dalam HATI, yang merupakan PENDORONG PSIKOLOGIS, misalnya MOTIF

${ }^{45}$ Kartini Muljadi dan Gunawan Wijaya, Perikatan Yang Lahir Dari Perjanjian, Cet. 6, (Jakarta: PT Rajagrafindo Persada, 2014), hlm. 95-96.

${ }^{46}$ Subekti (a), Loc.Cit. 
seseorang berinisial A membeli rumah, adalah menggunakan Uangnya agar Uang itu PRODUKTIF dengan cara MENGONTRAKkan rumah itu kelak. ${ }^{47}$ Sedangkan SEBAB/KAUSA PERSETUJUAN / PERJANJIAN menurut Hoge Raad, adalah SASARAN / TUJUAN yang hendak dicapai oleh kedua belah pihak dalam Perjanjian yang bersangkutan. (HR. 17 Nopember 1922, NJ. 1923, 155). ${ }^{48}$ Lebih lanjut Mahkamah Agung dalam putusannya Nomor 268 K/Sip/1971 dalam perkara perkara $N y$. Lie Lian Joun Vs Arthur Tutuima, memberi makna KAUSA hukum yang HALAL atau ALASAN yang DIPERBOLEHKAN itu merupakan TUJUAN BERSAMA (gezaameenlijk doel) dari kedua belah pihak sebagai dasar diadakannya Perjanjian yang bersangkutan dan BUKAN mengenai akibat pada waktu pelaksanaan Perjanjian. ${ }^{49}$ Perjanjian dengan kausa yang terlarang merupakan perjanjian dengan kausa sebagai berikut: ${ }^{50}$

1) Yang bertentangan dengan undang-undang, dimana objek perjanjian berupa prestasi merupakan tindakan yang dilarang oleh Undang-Undang.

2) Yang bertentangan dengan kesusilaan

3) Yang bertentangan dengan ketertiban umum.

Adanya suatu sebab (oorzaak ; causa) ini dimaksudkan tiada lain daripada isi perjanjian ${ }^{51}$ atau materi muatan yang diatur dalam suatu

${ }^{47}$ R. M. Suryodiningrat, Op.Cit, hlm. 110.

${ }^{48}$ Ibid.

${ }^{49}$ Ridwan Khairandy, Op.Cit, hlm. 188-189.

${ }^{50}$ J. Satrio (b), Hukum Perikatan: Perikatan Yang Lahir Dari Perjanjian Buku II, Cet. 1, (Bandung: PT Citra Adity Bakti, 1995), hlm. 98-127.

${ }^{51}$ Subekti (a), Loc.Cit. perjanjian tersebut tidak dilarang oleh undang-undang atau sesuai / tidak bertentangan dengan kesusilaan yang baik dan tidak bertentangan / sesuai dengan ketertiban umum. hal ini berkenaan pula dengan pelaksanaan perjanjian yang dilakukan dengan itikad baik.

Syarat pertama dan kedua dalam Pasal 1320 KUH Perdata tersebut, dalam hukum perdata disebut sebagai Syarat Subyektif. Sedangkan syarat ketiga dan keempat dalam Pasal 1320 KUH Perdata tersebut dalam hukum perdata disebut sebagai Syarat Objektif.

Tidak terpenuhinya syarat sahnya Perjanjian dapat berakibat hukum, Perjanjian tersebut BATAL DEMI HUKUM atau dapat dibatalkan. Suatu perjanjian dapat dibatalkan (vernietigbaar), apabila perjanjian tidak memenuhi syarat subjektif SAHnya suatu perjanjian. Hal ini berarti bahwa perjanjian dimaksud batal apabila ada pihak yang mengajukan Pembatalannya ke Pengadilan dan telah ada putusan Pengadilan yang telah berkekuatan hukum tetap (kracht van gewijsde) yang menyatakannya serta akibat hukum yang lahir / timbul sejak perjanjian tersebut dibuat sampai dengan dibatalkan oleh Pengadilan dianggap tetap SAH dan MENGIKAT, akan tetapi setelah Putusan yang membatalkan perjanjian tersebut telah berkekuatan hukum tetap (kracht van gewijsde), maka tidak ada lagi hubungan hukum (ikatan hak dan kewajiban) yang dapat dipenuhi berdasarkan perjanjian yang telah dibatalkan tersebut, bersifat prospektif.

Suatu perjanjian batal demi hukum (nietigbaar ; null and void), apabila perjanjian tidak memenuhi syarat objektif sahnya suatu perjanjian. hal 
ini berarti bahwa perjanjian dimaksud telah batal sejak semula / saat diadakannya perjanjian, dan akibat hukum yang lahir / timbul dari semula tidak ada suatu perjanjian dan tidak ada pula suatu perikatan antara para pihak yang membuat perjanjian dimaksud, sehingga tidak pernah ada suatu perjanjian diantara para pihak yang membuat perjanjian dimaksud sejak semula.

Konsekuensi hukum suatu perjanjian batal demi hukum adalah bahwa para pihak tidak dapat saling menuntut ganti rugi / pemenuhan prestasi atas perjanjian yang batal demi hukum tersebut meskipun telah berlangsung dalam waktu tertentu sampai akhirnya para pihak / salah satu pihak menyadari perjanjian dimaksud batal demi hukum, karena sejak semula tidak ada suatu ikatan hak dan kewajiban antara para pihak, bersifat retroaktif.

Unsur-unsur yang terdapat dalam suatu perjanjian secara umum ada 3 (tiga) yaitu unsur essensialia, unsur naturalia, unsur aksidentalia. ${ }^{52}$ unsur essensialia merupakan unsur atau bagian yang selalu harus ada dalam suatu perjanjian, unsur mutlak dimana tanpa adanya unsur tersebut, perjanjian tak mungkin ada..$^{53}$ tanpa keberadaan unsur essensialia tersebut, maka perjanjian yang dimaksudkan untuk dibuat dan diselenggarakan oleh para pihak dapat menjadi berbeda dan karenanya menjadi tidak sejalan dan tidak sesuai dengan kehendak para pihak, oleh karenanya unsur essensialia ini merupakan pembeda antara suatu perjanjian dengan perjanjian lainnya, terutama untuk 15 (lima belas) perjanjian

${ }^{52}$ J. Satrio (a), Op.Cit, hlm. 68.

${ }^{53}$ Ibid. bernama (nominaat) yang diatur dalam buku III KUH Perdata. $^{54}$ secara umum, "sebab yang halal" merupakan unsur essensialia untuk adanya perjanjian. ${ }^{55}$ Dalam perjanjian jual beli, harga dan barang yang disepakati kedua belah pihak merupakan unsur essensialia. ${ }^{56}$ Dalam perjanjian sewa menyewa, barang dan sewanya (harga sewa dan jangka waktu sewa) yang disepakati kedua belah pihak merupakan unsur essensialia. ${ }^{57}$ pada perjanjiaan riil, syarat penyerahan objek perjanjian merupakan unsur essensialia. ${ }^{58}$ bentuk tertentu merupakan unsur essensialia dalam perjanjian formil. ${ }^{59}$

Unsur naturalia adalah bagian perjanjian yang berdasarkan sifatnya dianggap ada tanpa perlu diperjanjikan secara khusus oleh para pihak atau unsur Perjanjian yang diatur dalam Undang-Undang terutama untuk 15 (lima belas) Perjanjian bernama (nominaat) yang diatur dalam buku III KUH Perdata, tetapi yang oleh para pihak dapat disimpangi atau diganti. ${ }^{60}$ Beberapa contoh bagian naturalia pada perjanjian jual beli sebagai berikut: ${ }^{61}$

- Biaya penyerahan barang ditanggung oleh penjual jika tidak telah diadakan persetujuan lain (Pasal 1476 KUH Perdata).

- Penanggungan yang menjadi kewajiban penjual terhadap

\footnotetext{
${ }^{54}$ Kartini Muljadi dan Gunawan Wijaya, Op.Cit., hlm. 88

${ }^{55}$ J. Satrio (a), Op.Cit, hlm. 67-68.

${ }^{56}$ Ibid.

${ }^{57}$ I.G. Rai Widjaya, Merancang Suatu Kontrak (Contract drafting) Teori Dan Praktek, Ed. Revisi, (Jakarta: Kesaint Blanck, 2003), hlm. 119.

${ }^{58} \mathrm{~J}$. Satrio (a), Op.Cit, hlm. 68.

${ }^{59}$ Ibid.

${ }^{60}$ Herlien Budiono (b), Op.Cit, hlm. 72. Lihat juga J. Satrio (a), Loc. Cit.

${ }^{61}$ Herlien Budiono (b), Loc..Cit.
} 
pembeli mengenai penguasaan

benda yang dijual secara aman

dan ten-teram dan terhadap adanya cacat-cacat barang yang tersembunyi (Pasal $1491 \mathrm{KUH}$ Perdata).

- Jika benda yang dijual berupa barang yang sudah ditentukan, barang ini sejak saat pembelian adalah atas tanggungan pembeli meskipun penyerahannya belum dilakukan dan penjual berhak menuntut harganya (Pasal 1460 KUH Perdata).

Bagian naturalia dari perjanjian sewa-menyewa adalah ketentuanketentuan, baik Undang-Undang Nomor 1 Tahun 2011 Tentang Perumahan Dan Kawasan Pemukiman $^{62}$ jo. Peraturan Pemerintah Nomor 44 Tahun 1994 Tentang Penghunian Rumah Oleh Bukan Pemilik ${ }^{63}$ maupun KUH Perdata yang sifatnya tidak memaksa. ${ }^{64}$ Contoh dari ketentuan yang bersifat mengatur yang merupakan bagian naturalia dari perjanjian sewa-menyewa adalah: ${ }^{65}$

- Jika barang yang disewakan musnah sebagian, penyewa dapat memilih meminta pengurangan harga sewa atau pembatalan. Namun, untuk kedua hal tersebut (ia) tidak berhak menuntut ganti

\footnotetext{
${ }^{62}$ Indonesia, Undang-Undang Tentang Perumahan Dan Kawasan Pemukiman, UU No. 1 Tahun 2011, Lembaran Negara Republik Indonesia Tahun 2011 Nomor 7, Tambahan Lembaran Negara Republik Indonesia Nomor 5188, untuk selanjutnya dalam penulisan ini cukup disebut dan disingkat "UU No. 1 Tahun 2011."

${ }^{63}$ Indonesia, Peraturan Pemerintah Tentang Penghunian Rumah Oleh Bukan Pemilik, PP No. 44 Tahun 1994, Lembaran Negara Republik Indonesia Tahun 1994 Nomor 73, Tambahan Lembaran Negara Republik Indonesia Nomor 3576, untuk selanjutnya dalam penulisan ini cukup disebut dan disingkat "PP No. 44 Tahun 1994."

${ }^{64}$ Ibid.

${ }^{65}$ Ibid., hlm 70-71.
}

rugi (Pasal 12 ayat (3) PP Nomor

44 Tahun 1994 jo. Pasal 1553

KUH Perdata).

- Penyewa dilarang mengubah bentuk bangunan rumah tanpa izin tertulis dari pemilik (Pasal 9 ayat (2) PP No. 44 Tahun 1994).

- Penyewa tidak berhak mengoperkan hak sewa / memindahkan hak penghunian atau mengulangsewakan / menyewakan kembali tanpa izin dari pemilik (Pasal 9 ayat (1) PP No. 44 Tahun 1994 jo. Pasal 1559 ayat (1) KUH Perdata). Apabila yang disewa didiami sendiri oleh penyewa, ia berhak untuk menyewakan sebagian rumah tersebut, kecuali dilarang dalam perjanjiannya (Pasal 1559 ayat (2) KUH Perdata).

- Perjanjian sewa-menyewa tidak berakhir dengan meninggalnya atau dibubarkannya (apabila badan hukum) salah satu pihak (Pasal 1575 KUH Perdata).

- Perjanjian sewa-menyewa tidak putus dengan dijualnya objek sewa, kecuali telah diperjanjikan sebelumnya. Jika ada perjanjian demikian, penyewa tidak berhak menuntut ganti rugi apabila tidak diperjanjikan dengan tegas (Pasal 13 PP No. 44 Tahun 1994 jo. Pasal 1576 KUH Perdata).

Unsur Aksidentalia (accidentalia) adalah bagian dari perjanjian berupa ketentuan yang diperjanjikan secara khusus oleh para pihak. Misalnya, termin (jangka waktu) pembayaran, pilihan domisili, pilihan hukum, dan cara penyerahan barang. ${ }^{66}$ Atau Unsur essensialia adalah unsur perjanjian yang ditambahkan oleh para pihak, Undang-Undang sendiri

${ }^{66} I$ bid., hlm 71. 
tidak mengaturnya. ${ }^{67}$

Contoh dari ketentuan accidental pada perjanjian sewa-menyewa adalah sebagai berikut: ${ }^{68}$

- Pilihan hukum dan pilihan domisili.

- Cara pembayaran uang sewa.

- Denda atas keterlambatan penyerahan kembali setelah sewa berakhir.

- Pengaturan pembayaran rekening listrik, air, telepon, pajak bumi dan bangunan, iuran RT, dan asuransi.

Singkatnya, bagian accidentalia pada perjanjian sewa-menyewa adalah bagian yang tidak termasuk, baik ke dalam bagian essentialia maupun naturalia dari perjanjian sewa-menyewa. ${ }^{69}$ Sedangkan untuk menilai kapan saat lahir / timbulnya suatu perjanjian / persetujuan ada 5 (lima) teori ${ }^{70}$ yang harus diperhatikan secara seksama.

2. Wujud Pernyataan Kehendak (Kesepakatan) Dalam Suatu Perjanjian

${ }^{67} \mathrm{~J}$. Satrio (a), Loc. Cit.

${ }^{68}$ Herlien Budiono (b), Op.Cit., hlm 71.

${ }^{69} \mathrm{Ibid}$.

${ }^{70}$ Ada 5 (lima) teori yaitu: Pertama Teori PERNYATAAN (Uitingstheorie), menurut Teori ini, PERJANJIAN TELAH ADA pada SAAT - atas suatu PENAWARAN - TELAH DIJAWAB / DITERIMA / DISETUJUI oleh Pihak yang MENERIMA TAWARAN (Akseptasi oleh Akseptor); Kedua Teori PENGIRIMAN (Verzendingstheorie), menurut Teori ini, SAAT PENGIRIMAN JAWABAN AKSEPTASI adalah SAAT LAHIRnya PERJANJIAN; Ketiga Teori PENGETAHUAN (Vernemingstheorie), menurut Teori ini, pada SAAT JAWABAN DIKETAHUI ISInya oleh orang yang MENAWARKAN, maka PERJANJIAN itu ada; Keempat Teori PITLO, menurut Teori ini, PERJANJIAN LAHIR, pada SAAT orang yang memberikan JAWABAN / TANGGAPAN menganggap bahwa PIHAK yang MENAWARKAN itu TELAH MENGETAHUI JAWABANnya; Kelima Teori PENERIMAAN (Ontvangstheorie), menurut Teori ini, PERJANJIAN LAHIR, pada SAAT orang yang MENAWARKAN itu MENERIMA JAWABAN dari PIHAK yang DITAWARKAN. Lihat J. Satrio (b), Op.Cit., hlm. 256-264.
Untuk pernyataan kehendak (kesepakatan) yang terikat dapat dalam suatu perjanjian dilakukan dengan 3 (tiga) wujudnya, yaitu:

Pertama Lisan (Tidak Tertulis). Pernyataan Kehendak dapat dilakukan secara tegas dan juga secara diam-diam baik tertulis atau lisan. Pernyataan Kehendak yang dilakukan secara LISAN dapat dilakukan dengan rangkaian kata / kalimat yang sempurna maupun yang tidak sempurna tapi dimengerti oleh pihak mitra dalam Perjanjian atau KESEPAKATAN atau PERSETUJUAN itu, misalnya A menawar menawarkan sepeda antik miliknya kepada B dengan harga Rp 20.000.000,-, apabila B SETUJU dengan PENAWARAN A tersebut, dapat menyatakan dengan kalimat "Saya setuju untuk membeli sepeda antik milik $A$ dengan harga $R p$ 20.000.000,tersebut." atau B dapat juga menyatakan "ya, saya setuju." 11 Perjanjian dapat dibuat secara lisan maupun tertulis. Apabila suatu PERSETUJUAN atau PERJANJIAN dibuat secara TIDAK TERTULIS atau LISAN dinamakan PERSETUJUAN atau PERJANJIAN ${ }^{72}$ atau KESEPAKATAN.

Kedua Tertulis (Tulisan atau Tersurat). pernyataan kehendak sebagai persetujuan atau perjanjian dapat dilakukan dengan cara tertulis, dengan melihat tandatangan para pihak dalam perjanjian tertulis dimaksudkan sebagai tanda persetujuannya masing-masing pihak. $^{73}$ Apabila suatu perjanjian dibuat secara tertulis, maka perjanjian

\footnotetext{
${ }^{71}$ Ridwan Khairandy, Op.Cit, hlm. 170-171.

${ }^{72}$ Subekti (a), Loc.Cit.

${ }^{73}$ Ridwan Khairandy, Loc.Cit.
} 
tersebut dinamakan kontrak $^{74}$ dalam praktek ditulis dengan aneka format ataupun istilah, misalnya Surat Perjanjian Jual Beli Saham, Kontrak Sewa Menyewa Mobil, dll. Dari ketentuan yang diatur dalam Pasal $1867^{75}$ KUH Perdata dapat diketahui bahwa tulisan terdiri atas 2 (dua) macam tulisan yaitu tulisan otentik atau tulisan resmi (authentiek) dan tulisan di bawah tangan (onderhands). ${ }^{76}$ Akta Otentik, Pengertian dan makna akta otentik diatur dalam Pasal $1868^{77} \mathrm{KUH}$ Perdata dan Pasal $165^{78}$ HIR/Pasal $185 \mathrm{RBg}$, dengan unsur-unsur sebagai berikut:

1) akta itu harus dibuat oleh atau dihadapan seorang Pejabat Umum. Akta otentik terutama memuat keterangan seorang pejabat, yang menerangkan apa yang dilakukannya dan dilihat dihadapannya. ${ }^{79} \quad$ Sebagai keterangan dari seorang pejabat bahwa apa yang dikatakan pejabat

${ }^{74}$ Ibid. Perkataan kontrak, lebih sempit karena ditujukan kepada perjanjian atau persetujuan yang tertulis.

${ }^{75} \mathrm{KUH}$ Perdata Pasal 1867 "Pembuktian dengan tulisan dilakukan dengan tulisan-tulisan otentik maupun dengan tulisan-tulisan dibawah tangan."

${ }^{76}$ R. Subekti (b), Hukum Pembuktian, Cet. 8, (Jakarta: Penerbit Pradnya Paramita, 1987), hlm. 178.

${ }^{77}$ KUH Perdata Pasal 1868 "Suatu akta otentik ialah suatu akta yang didalam bentuk yang ditentukan oleh undang-undang, dibuat oleh atau dihadapan pegawai-pegawai umum yang berkuasa untuk ditempatkan dimana akte dibuatnya."

${ }^{78} \mathrm{HIR}$ Pasal 165 "Akte otentik, yaitu suatu surat yang diperbuat oleh atau dihadapan pegawai umum yang berkuasa akan membuatnya, mewujudkan bukti yang cukup bagi kedua belah pihak dan ahli warisnya serta sekalian orang yang mendapat hak daripadanya, yaitu tentang segala hal, yang tersebut didalam surat itu dan juga tentang yang tercantum dalam surat itu sebagai pemberitahuan sahaja, tetapi yang tersebut kemudian itu hanya sekedar yang diberitahukan itu langsung berhubungan dengan pokok dalam akte itu." Mr R. Tresna, Komentar HIR, Cet. 18, (Jakarta: PT Pradnya Paramita, 2005), hlm. 142.

${ }^{79}$ Sudikno Mertokusumo (b), Hukum Acara Perdata Indonesia, Ed. 6, (Yogyakarta: Liberty, 2002), hlm. 123. itu adalah sebagai yang dilihatnya dianggap sebagai benar terjadi dihadapannya, maka kekuatan pembuktiannya berlaku bagi setiap orang. Karena akta otentik itu merupakan risalah dari pejabat, maka hanyalah merupakan bukti daripada apa yang terjadi dihadapannya saja. ${ }^{80}$

Pejabat umum yang dimaksud adalah pejabat yang diberi wewenang berdasarkan Undangundang dalam batas wewenang yang telah ditetapkan dengan tegas dan jelas dalam Undangundang yang bersangkutan, misalnya notaris, hakim, jurusita pada suatu Pengadilan, Pegawai pencatatan sipil (ambtenaar burgerlijke stand) dan sebagainya. Secara garis besar pejabat yang berwenang membuat akta otentik antara lain sebagai berikut: ${ }^{81}$

a) Di bidang hukum publik oleh Pejabat Tata Usaha Negara (Pejabat TUN), seperti Kartu Tanda Penduduk (KTP), Surat Izin Mengemudi (SIM), Izin Mendirikan Bangunan (IMB), Izin Pergudangan, Passpor dan sebagainya, semuanya dibuat oleh Pejabat TUN. Namun demikian, ada juga akta otentik tertentu yang dibuat oleh Pejabat Yudikatif, seperti Berita Acara Sidang, Surat Penanggalan, Berita Acara Sita, Akta Banding atau Kasasi, yang dibuat oleh Panitera atau jurusita, penetapan atau putusan pengadilan yang dibuat oleh Hakim yang

${ }^{80} \mathrm{Ibid}$, hlm. 124.

${ }^{81}$ M. Yahya Harahap (b), Hukum Acara Perdata: Gugatan, Persidangan, Penyitaan, Pembuktian, dan Putusan Pengadilan, Ed. 2, Cet. 1, (Jakarta: Sinar Grafika, 2017), hlm. 644-646. 
memeriksa, memutus dan mengadili perkara yang bersangkutan.

b) Di bidang hukum perdata oleh Notaris. Pada umumya akta otentik yang meyangkut bidang perdata, dibuat dihadapan Notaris, sebagaimana dimaksud dan berdasarkan Undang-Undang Nomor 30 Tahun 2004 Tentang Jabatan Notaris $^{82}$ sebagaimana diubah dengan Undang-Undang Nomor 2 Tahun 2014 Tentang Perubahan Undang-Undang Nomor 30 Tahun 2004 Tentang Jabatan Notaris. ${ }^{83}$

Salah satu AKTA OTENTIK adalah AKTA NOTARIS (vide Pasal $1868^{84}$ KUH Perdata Jo. Pasal $165^{85}$ HIR/Pasal 185 RBg

${ }^{82}$ Indonesia, Undang-Undang Tentang Jabatan Notaris, UU No. 30 Tahun 2004, Lembaran Negara Republik Indonesia Tahun 2004 Nomor 117, Tambahan Lembaran Negara Republik Indonesia Nomor 4432, untuk selanjutnya dalam penulisan ini cukup disebut dan disingkat "UU No. 30 Tahun 2004" atau "UU 30/2004."

${ }^{83}$ Indonesia, Undang-Undang Tentang Perubahan Atas Undang-Undang Nomor 30 Tahun 2004 Tentang Jabatan Notaris, UU No. 2 Tahun 2014, Lembaran Negara Republik Indonesia Tahun 2014 Nomor 3, Tambahan Lembaran Negara Republik Indonesia Nomor 5491, untuk selanjutnya dalam penulisan ini cukup disebut dan disingkat "UU No. 2 Tahun 2014" atau "UU 2/2014."

${ }^{84}$ Pasal 1868 KUH Perdata "Suatu AKTA OTENTIK ialah suatu AKTA yang didalam BENTUK yang DITENTUKAN oleh Undang-Undang, dibuat oleh atau dihadapan pegawai-pegawai UMUM yang BERKUASA untuk itu DI TEMPAT di mana AKTA DIBUATnya."

${ }^{85}$ HIR Pasal 165 "Akte otentik, yaitu suatu surat yang diperbuat oleh atau dihadapan pegawai umum yang berkuasa akan membuatnya, mewujudkan bukti yang cukup bagi kedua belah pihak dan ahli warisnya serta sekalian orang yang mendapat hak daripadanya, yaitu tentang segala hal, yang tersebut didalam surat itu dan juga tentang yang tercantum dalam surat itu sebagai pemberitahuan sahaja, tetapi yang tersebut kemudian itu hanya sekedar yang diberitahukan itu langsung berhubungan dengan pokok dalam akte itu." Mr R. Tresna, Komentar HIR, Cet. 18, (Jakarta: PT Pradnya Paramita, 2005), hlm. 142.
Jo. Pasal 1 angka $7^{86}$ Undang-

Undang Jabatan Notaris). Akan tetapi dalam hal tertentu bisa juga Pejabat TUN seperti akta nikah dibuat dihadapan Pegawai Pencatatan Nikah (PPN) di Kantor Urusan Agama (KUA) bagi mereka yang beragama Islam dan dihadapan Pegawai Catatan Sipil bagi yang non Islam.

Akta otentik itu dapat dibedakan 2 (dua) bagian besar sebagai berikut: 87

(1) akta yang dibuat oleh (door) ${ }^{88}$ Pejabat (ambtelijke aktan, acte ambtelik, procesverbaal acte, acta relaas). Akta yang dibuat oleh Pejabat yang diberi wewenang untuk itu dengan mana pejabat tersebut menerangkan apa yang dilihat serta apa yang dilakukannya.

Pada umumnya akta otentik yang dibuat dihadapan pejabat yang berwenang, berdasarkan permohonan dari yang berkepentingan.

Namun ada juga tanpa permintaan dari yang berkepentingan, tetapi pembuatannya dikaitkan dengan fungsi tertentu seperti pembuatan Berita Acara oleh Notaris atau Putusan pengadilan, dibuat berdasarkan pelaksanaan fungsi penegakan hukum yang ditentukan Undang-

${ }^{86}$ Pasal 1 angka 7 "Akta Notaris yang selanjutnya disebut Akta adalah akta autentik yang dibuat oleh atau di hadapan Notaris menurut bentuk dan tata cara yang ditetapkan dalam Undang-Undang ini."

${ }^{87}$ H.R. Daeng Naja, Teknik Pembuatan Akta (Buku Wajib Kenotariatan), Cet. 1, (Yogyakarta: Pustaka Yustisia, 2012), hlm. 15. Sudikno Mertokusumo (b), Loc.Cit. M. Yahya Harahap (b), Op.Cit, hlm. 647.

${ }^{88}$ G.H.S. Lumban Tobing, Peraturan Jabatan Notaris Di Indonesia, (Jakarta: PT Erlangga, 1980), hlm. 4. 
undang dalam hal ini hukum acara. Jadi inisiatifnya atau kehendak atau keinginan tidak berasal dari orang yang namanya diterangkan dalam akta itu.

(2) akta yang dibuat dihadapan (ten overstaan) ${ }^{89}$ Pejabat (aktan overstaan) oleh para pihak yang memerlukannya (partij aktan) atau yang dibuat oleh para pihak dihadapan Pejabat (partij acte). Akta yang dibuat dihadapan pejabat yang berwenang untuk itu, dengan akta itu pejabat menerangkan juga apa yang dilihat serta dilakukannya. Para pihak atas kemauan mereka sendiri, datang ke kantor Pejabat. Dihadapan pejabat para pihak memberi atau meyampaikan keterangan sendiri atau keterangan yang disampaikan dapat berbentuk lisan atau tulisan, lalu para pihak meminta kepada pejabat, agar keterangan yang mereka sampaikan dituangkan dalam bentuk akta. Misalnya akta notaris.

2) akta itu dibuat dalam bentuk yang ditentukan oleh Undang-undang. Dalam pembuatan akta otentik tersebut, Pejabat terikat pada syarat-syarat dan ketentuan dalam Undang-undang, sehingga hal itu merupakan jaminan dapat dipercayainya pejabat tersebut, maka daripada itu akta otentik itu cukup dibuktikan oleh akta itu sendiri.

3) pejabat umum oleh atau dihadapan siapa akta itu dibuat, harus mempunyai kewenangan untuk membuat akta itu. Pejabat yang membuat akta tersebut berwenang untuk membuat akta otentik tersebut karena jabatan (ambt) baik berdasarkan pengangkatan ataupun karena penunjukan yang diperintahkan / diamanatkan oleh Undang-undang. Pejabat tersebut memang berwenang membuat akta otentik tersebut baik dari jenis dan materi muatan akta otentik dimaksudkan, maupun juga dari segi para pihak yang menghadap atau pihak-pihak yang meminta dibuatkan akta otentik tersebut.

4) Pejabat umum membuat akta dalam daerah / wilayah kerjanya. Pejabat yang membuat akta tersebut hanya berwenang membuat akta otentik di dalam wilayah kerjanya dan atau di wilayah kedudukannya sesuai dengan yang ditetapkan dalam surat keputusan pengangkatan / penunjukannya berdasarkan ketentuan yang diatur dalam Undang-undang tertentu yang mendasari kewenangan Pejabat tersebut.

Surat dibawah tangan. Surat di bawah tangan ialah surat yang sengaja dibuat untuk pembuktian oleh para pihak tanpa bantuan atau tanpa perantaraan dari seorang pejabat. ${ }^{90}$ Misalnya surat perjanjian jual beli atas sewa menyewa yang dibuat sendiri oleh kedua belah pihak yang mengadakan perjanjian itu.

Ketiga dengan tanda. pernyataan kehendak dapat pula diungkapkan dengan tanda atau tanda penyartaan kehendak baik berupa gambar, simbol tertentu, misalnya berjabatan tangan

${ }^{90}$ Sudikno Mertokusumo (b), Op.Cit., hlm. 127. R. Subekti (b), Op.Cit., hlm. 179. 
dalam pertemuan pembahasan suatu Perjanjian.

\section{METODE PENELITIAN}

Penelitian $^{91}$ ini merupakan penelitian hukum atau kajian hukum, ${ }^{92}$ oleh karenanya metode ${ }^{93}$ penelitian $^{94}$ yang dipilih dan dipergunakan adalah metode penelitian hukum yaitu metode penelitian hukum normatif (penelitian yuridis normatif) ${ }^{95}$ atau penelitian

\footnotetext{
${ }^{91}$ Penelitian (research) merupakan upaya pencarian kembali yang amat bernilai edukatif disebabkan oleh hasrat ingin tahu dari manusia yang dipertanyakannya. Lihat Amirudin dan Zainal Asikin, Pengantar Metode Penelitian Hukum, Ed. 1, Cet. 3, (Jakarta: PT Raja Grafindo Persada, 2006), hlm 19. Penelitian merupakan suatu sarana pokok dalam pengembangan ilmu pengetahuan dan teknologi, oleh karena penelitian bertujuan untuk mengungkapkan kebenaran secara sistematis, metodologis dan konsisten, dengan mengadakan analisa dan konstruksi. Lihat juga: Soerjono Soekanto dan Sri Mamudji, Penelitian Hukum Normatif Suatu Tinjauan Singkat, Ed. 1, Cet. 5, (Jakarta: PT. RajaGrafindo Persada, 2001), hlm. 20.

${ }^{92}$ Kajian hukum berarti menggunakan disiplin
} hukum. Disiplin hukum, menurut Soerjono Soekanto dan Sri Mamudji, adalah suatu sistem ajaran tentang hukum sebagai norma dan sebagai kenyataan (= perilaku atau sikap tindak. Artinya, disiplin hukum menyoroti hukum sebagai sesuatu yang dicita-citakan, maupun sebagai suatu realitas. Lihat: Soerjono Soekanto dan Sri Mamudji, Op.Cit., hlm. 2.

${ }^{93}$ Metode, secara etimologis berasal dari bahasa Yunani, yakni kata "methodos, yang berarti "cara atau jalan," sedangkan metodologi, yaitu pengetahuan tentang berbagai cara kerja yang disesuaikan dengan objek studi (penelitian) ilmu yang bersangkutan. Lihat Fuad Hasan dan Koentjaraningrat, "Beberapa Azas Metodologi Ilmiah," dalam Koentjaraningrat (Ed.), Metode-metode Penelitian Masyarakat, Cet. 9, (Jakarta: PT. Gramedia Jakarta, 1989), hlm. 7 - 8. Sementara itu, metode penelitian adalah cara atau jalan atau proses pemeriksaan atau penyelidikan yang menggunakan cara penalaran dan berpikir yang logis-analitis (logika), berdasarkan dalil-dalil, rumus-rumus dan teori-teori suatu ilmu (atau beberapa cabang ilmu) tertentu, untuk menguji kebenaran (atau mengadakan verifikasi) suatu hipotesis atau teori tentang gejala-gejala atau peristiwa alamiah, peristiwa sosial atau peristiwa hukum tertentu. Lihat pula C. F. G. Sunarjati Hartono, Penelitian Hukum Di Indonesia Pada Akhir Abad Ke-20, Cet. 1, (Bandung: Alumni, 1994), hlm. 10.

${ }^{94}$ Metode penelitian adalah suatu cara atau jalan untuk memperoleh kembali pemecahan terhadap segala permasalahan dengan menerapkan salah satu metode yang relevan terhadap permasalahan tersebut. Lihat. Joko Subagyo, Metode Penelitian Dalam Teori Dan Praktek, (Jakarta: Rineka Cipta, 2004), hlm. 2

${ }^{95}$ Penelitian hukum normatif atau penelitian hukum kepustakaan adalah penelitian hukum yang hukum doktrinal (doctrinal research) ${ }^{96}$ atau penelitian hukum kepustakaan (library research),$^{97}$ dengan cara meneliti bahan pustaka.

Kemudian pendekatan penelitian hukum $^{98}$ yang digunakan dalam

dilakukan dengan cara meneliti bahan pustaka atau data sekunder belaka. Penelitian hukum normatif atau penelitian hukum kepustakaan tersebut mencakup penelitian terhadap asas-asas hukum dan penelitian terhadap taraf sinkronisasi vertikal dan horizontal. Lihat: Soerjono Soekanto dan Sri Mamudji, Op.Cit., hlm. 1314. Nama lain dari penelitian hukum normatif adalah penelitian hukum doktriner, juga disebut sebagai penelitian perpustakaan atau studi dokumen atau studi kepustakaan. Disebut penelitian hukum doktriner, karena penelitian ini dilakukan atau ditujukan hanya pada peraturan-peraturan yang tertulis atau bahan-bahan hukum yang lain. Sebagai penelitian perpustakaan ataupun studi dokumen disebabkan penelitian ini lebih banyak dilakukan terhadap data yang bersifat sekunder yang ada di perpustakaan. Lihat pula Bambang Waluyo, Penelitian Hukum Dalam Praktek, Ed. 1, Cet. 2, (Jakarta: Sinar Grafika, 1996), hlm. 13-14. Penelitian hukum normatif menggunakan studi kasus hukum normatif berupa produk perilaku hukum, misalnya mengkaji suatu undang-undang. Pokok kajiannya adalah hukum yang dikonsepsikan sebagai norma atau kaidah yang berlaku dalam masyarakat dan menjadi acuan perilaku setiap orang. Lihat juga: Abdulkadir Muhammad, Hukum dan Penelitian Hukum, Cet. 1, (Bandung: PT. Citra Aditya Bakti, 2004), hlm. 52.

${ }^{96}$ Penelitian hukum doktrinal, menurut Soetandyo Wighjosoebroto sebagaimana dikutip oleh Bambang Sunggono, terdiri dari (1) penelitian yang berupa usaha inventarisasi hukum positif, (2) penelitian yang berupa usaha penemuan asas dan dasar falsafah (dogma atau doktrin) hukum positif, (3) penelitian yang berupa usaha penemuan hukum in concreto yang layak diterapkan untuk menyelesaikan suatu perkara hukum tertentu. Lihat Bambang Sunggono, Metodologi Penelitian Hukum (Suatu Pengantar), Ed. 1., Cet. 3, (Jakarta: PT. Raja Grafindo Persada, 2001), hlm. 43.

${ }^{97}$ Ronny Hanitijo Soemitro, Metodologi Penelitian Hukum Dan Jurimetri, Cet. ke-3, (Jakarta: Ghalia Indonesia, 1988), hlm. 9.

${ }^{98}$ Dengan pendekatan penelitian hukum, peneliti akan mendapatkan informasi dari berbagai aspek mengenai isu yang sedang dicoba untuk dicari jawabannya. Pendekatan-pendekatan yang digunakan di dalam penelitian hukum adalah 1. pendekatan undangundang (statute approach), 2. pendekatan kasus (case approach), 3. pendekatan historis (historical approach), 4. pendekatan komparatif (comparative approach), dan 5. pendekatan konseptual (conceptual approach). Lihat Peter Mahmud Marzuki, Penelitian Hukum, Ed. Revisi, Cet. 8, (Jakarta: Kencana, Prenada Media Grup, 2013), hlm. 133. Cara pendekatan (approach) yang digunakan dalam suatu penelitian normatif akan memungkinkan seorang peneliti untuk memanfaatkan hasil-hasil temuan ilmu hukum empiris dan ilmu-ilmu lain untuk kepentingan dan analisis serta 
penelitian ini adalah statute approach (pendekatan undang-undang) dengan menelaah berbagai peraturan perundang-undangan regulasi yang berkaitan dengan pengaturan pinjam meminjam uang, ${ }^{99}$ disamping itu,

eksplanasi hukum tanpa mengubah karakter ilmu hukum sebagai ilmu normatif. Berbagai bahan hukum banyak yang memiliki sifat empiris seperti perbandingan hukum, sejarah hukum, dan kasus-kasus hukum yang telah diputus. Sebagaimana telah dibahas sebelumnya bahwa ilmu hukum normatif dapat dan harus memanfaatkan berbagai temuan ilmu lain, serta berinteraksi secara positif dengan ilmu-ilmu lain, khususnya ilmu hukum empiris. Dalam kaitannya dengan penelitian normatif dapat digunakan beberapa pendekatan berikut: 1 . Pendekatan Perundang-undangan (statute approach); 2. Pendekatan Konsep (conceptual approach); 3. Pendekatan Analitis (analytical approach); 4. Pendekatan Perbandingan (comparative approach); 5. Pendekatan Historis (historical approach); 6. Pendekatan Filsafat (philosophical approach); 7. Pendekatan Kasus (case approach). Cara pendekatan tersebut dapat digabung sehingga dalam suatu penelitian hukum normatif dapat saja menggunakan dua pendekatan atau lebih yang sesuai, misalnya pendekatan perundangundangan, pendekatan historis, dan pendekatan perbandingan. Lihat pula Jhonny Ibrahim, Teori Dan Metodologi Penelitian Hukum Normatif, Ed. Revisi, Cet.3., (Malang: Bayumedia Publishing, 2007), hlm. 300 -301 .

${ }^{99}$ Pendekatan undang-undang (statute approach) dilakukan dengan menelaah semua undang-undang dan regulasi yang bersangkut paut dengan isu hukum yang sedang ditangani. Bagi penelitian untuk kegiatan praktis, pendekatan undang-undang ini akan membuka kesempatanbagi peneliti untuk mempelajari adakah konsistensi dan kesesuaian antara suatu undang-undang dengan undang-undang lainnya atau antara undang-undang dan Undang-Undang Dasar atau antara regulasi dan undang-undang. Hasil dari telaah tersebut merupakan suatu argumen untuk memecahkan isu yang dihadapi. Bagi penelitian untuk kegiatan akademis, peneliti perlu mencari ratio legis dan dasar ontologis lahirnya undang-undang tersebut. Dengan mempelajari ratio legis dan dasar ontologis suatu undang-undang, peneliti sebenarnya mampu menangkap kandungan filosofi yang ada di belakang undang-undang. itu. Memahami kandungan filosofi yang ada di belakang undangundang itu, peneliti tersebut akan dapat menyimpulkan mengenai ada tidaknya benturan filosofis antara undang-undang dengan isu yang dihadapi. Lihat Peter Mahmud Marzuki, Op.Cit., hlm. 133-134. Suatu penelitian normatif tentu harus menggunakan pendekatan perundang-undangan, karena menelaah hubungan dan konsistensi pengaturan pinjam meminjam uang.

Data $^{100}$ yang digunakan dalam penelitian ini adalah data sekunder ${ }^{101}$ yang diperoleh dari bahan hukum berupa Pertama, bahan hukum primer yang meliputi Kitab Undang-Undang Hukum Perdata (KUH Perdata), Het Hierziene Indonesich Reglement (HIR), UU No. 34 Tahun 2004, UU No. 1 Tahun 2011, UU No. 3 Tahun 2014, PP No. 44 Tahun 1994. Kedua, bahan hukum sekunder yang meliputi lieratur dan kajian-kajian dalam bidang hukum perdata berupa kajian-kajian para ahli hukum berkenaan dengan pinjam meminjam uang pada khususnya, dan lainnya yang memiliki hubungan dengan pembahasan makalah ini. Ketiga, bahan hukum tersier yang berupa ensiklopedia dan kamus-kamus.

Bahan-bahan hukum yang telah terkumpul kemudian diolah dan dianalisis dengan menggunakan metode

yang akan diteliti adalah berbagai aturan hukum yang menjadi fokus sekaligus tema sentral suatu penelitian. Lihat pula Jhonny Ibrahim, Op.Cit., hlm. 302.

${ }^{100}$ Data, secara etimologis berasal dari bahasa Latin, dengan akar kata "do" yang artinya memberi; menunjukkan; menganugerahkan; menyerahkan. "data" adalah bentuk Jamak (Plural) dari "datum" yang Tunggal (Singular). Lihat Peter Mahmud Marzuki, Op.Cit., hlm. 59, dalam Catatan Kaki Nomor 8.

${ }^{101}$ Menurut tempat diperolehnya, data dalam penelitian dibedakan antara data primer dan data sekunder. Data primer adalah data yang diperoleh langsung dari masyarakat, sedangkan data sekunder adalah data yang diperoleh dari kepustakaan. Lihat Sri Mamudji, Et.al, Metode Penelitian Dan Penulisan Hukum, Cet. 1, Depok: Badan Penerbit FH UI, 2005, hlm. 6. Adapun data sekunder tersebut memiliki ciri-ciri umum sebagai berikut: 1) data sekunder pada umumnya ada dalam keadaan siap terbuat (ready made); 2) bentuk maupun isi data sekunder telah dibentuk dan diisi oleh peneliti-peneliti terdahulu.; 3) data sekunder dapat diperoleh tanpa terikat atau dibatasi oleh waktu dan tempat. Dengan adanya data sekunder tersebut, seorang peneliti tidak perlu mengadakan penelitian sendiri dan secara langsung terhadap faktor-faktor yang menjadi latar belakang penelitiannya sendiri. Lihat pula: Soerjono Soekanto dan Sri Mamudji, Op.Cit., hlm. 24. 
penafsiran hukum dan metode konstruksi hukum.

Seluruh data yang berhasil dikumpulkan kemudian disortir dan diklasifikasikan, kemudian disusun melalui susunan yang komprehensif. Proses analisis diawali dari premispremis yang berupa norma hukum positif yang diketahui dan berakhir pada analisis dengan menggunakan asas-asas hukum, doktrin-doktrin serta teori-teori.

Metode analisis data yang dipergunakan dalam penelitian ini adalah metode analisis kualitatif, dengan meneliti data yang diperoleh secara mendalam dari berbagai segi, ${ }^{102}$ tidak selalu ditentukan oleh jumlah (kuantitas) peristiwa yang terjadi, dan tidak menggunakan konsep-konsep yang diukur atau dinyatakan dengan angka atau rumusan statistik, tetapi lebih menekankan proses daripada hasil atau produk. ${ }^{103}$ Dalam menganalisis data sekunder tersebut, penguraiaan data disajikan dalam bentuk kalimat yang konsisten, logis dan efektif serta sistematis sehingga memudahkan untuk interpretasi data dan kontruksi data serta pemahaman akan analisis yang dihasilkan. Pengolahan data pada hakikatnya merupakan kegiatan untuk mengadakan sistematisasi ${ }^{104}$ terhadap bahan-bahan hukum.

${ }^{102}$ Norman K. Denzin \& Yvona S. Lincoln, ed. Handbook of Qualitative Research dikutip dari Natasya Yunita Sugiastuti, Tradisi Hukum Cina: Negara Dan Masyarakat (Studi Mengenai Peristiwa-peristiwa Hukum di Pulau Jawa Zaman Kolonial (1870-1942), Cet. 1, Jakarta: Program Pasca Sarjana Fakultas Hukum Universitas Indonesia, 2003, hlm. 19.

${ }^{103}$ John W. Creswell. Research Design of Qualitative \& Quantitative Approches, dalam Natasya Yunita Sugiastuti, Ibid.

${ }^{104}$ Sistematisasi berarti membuat klasifikasi terhadap bahan-bahan hukum tersebut untuk memudahkan pekerjaan analisis dan konstruksi. Soerjono Soekanto (1), Pengantar Penelitian Hukum, Cet. 3, Jakarta: UI Press, 1986, hlm. 251-252.
Hasil penelitian ini bersifat deskriptif analitis yaitu memaparkan, atau mengambarkan peraturan hukum yang berlaku dikaitkan dengan teori-teori hukum dan praktek pelaksanaan hukum positif. Deskripsi yang diberikan dalam penelitian ini adalah gambaran secara menyeluruh dan sistematis mengenai pengaturan pinjam meminjam uang secara lisan. Sedangkan dikatakan analitis, karena akan dilakukan analisis terhadap berbagai aspek hukum yang mengatur tentang pinjam meminjam uang secara lisan.

Akhirnya sebagai cara untuk menarik kesimpulan dari hasil penelitian yang sudah terkumpul, digunakan metode berfikir deduktif. ${ }^{105}$ Dengan menggunakan metode deduktif akan selalu menempatkan kaidah hukum dalam peraturan perundangan, prinsip-prinsip hukum, dan ajaran atau doktrin hukum sebagai premis mayor dan fakta atau peristiwa hukum sebagai premis minor yang dirangkai secara sistematis sebagai susunan fakta-fakta hukum untuk memberikan gambaran tentang pinjam meminjam uang secara lisan. ${ }^{106}$

\section{Hasil Dan Pembahasan}

A. Pengaturan Pinjam Meminjam Uang Istilah Perjanjian Pinjam Meminjam Uang ini, sering ditemukan juga dengan istilah pinjam meminjam uang atau peminjaman uang atau pinjaman uang.

Perjanjian Pinjam Meminjam Uang dalam KUH Perdata belum memperoleh pengaturan KHUSUS, akan tetapi para ahli bersepakat bahwa

${ }^{105}$ Metode berpikir deduktif, yaitu pengambilan kesimpulan dari pernyataan yang bersifat umum ke suatu pernyataan yang bersifat khusus. Lihat: Winarno Surakhmad, Pengantar Penelitian Ilmiah, Dasar Metode dan Teknik, Ed. 7, (Bandung: Tarsito, 1984), hlm. 134.

${ }^{106}$ Peter Mahmud Marzuki, Op.Cit, hlm. 83-94. 
Perjanjian Pinjam Meminjam Uang merupakan bentuk KHUSUS dari PERJANJIAN PINJAM MEMINJAM yang diatur dalam Bab XIII Pinjam Meminjam, terdiri dari 16 (enam belas) Pasal (Pasal 1754 sampai dengan Pasal 1769) dan 4 (empat) bagian yaitu :

1) Bagian Kesatu Ketentuan-ketentuan Umum, terdiri dari 5 (lima) Pasal (Pasal 1754 sampai dengan Pasal 1758);

2) Bagian Kedua Kewajiban-kewajiban Orang Yang Meminjamkan, terdiri dari 4 (empat) Pasal (Pasal 1759 d sampai dengan Pasal 1762);

3) Bagian Ketiga Kewajiban-kewajiban Si Peminjam, terdiri dari 2 (dua) Pasal (Pasal 1763 sampai dengan Pasal 1764);

4) Bagian Keempat Meminjam Dengan Bunga, terdiri dari 5 (lima) Pasal (Pasal 1765 sampai dengan Pasal 1769)

Istilah perjanjian pinjam meminjam barang ini dikenal juga dengan istilah pinjam mengganti.

Istilah lain yang sering dikaitkan dengan perjanjian pinjam meminjam barang atau pinjam mengganti ini adalah perjanjian pinjam pakai barang atau dikenal juga dengan istilah pinjam pakai.

Dalam lalu lintas kehidupan seharihari istilah pinjam pakai dengan istilah pinjam mengganti ini sering disamakan sehingga campur aduk makna, dikatakan antara A dan B terjadi Perjanjian Pinjam Pakai, nyatanya dalam perspektif hukum unsur-unsur atau karakteristik yang mencocokinya adalah Perjanjian Pinjam Meminjam, begitu juga sebaliknya.

Pinjam Meminjam adalah suatu perjanjian dengan mana pihak yang satu meberikan kepada pohak yang lain sesuatu jumlah uang atau barang- barang yang menghabis karena pemakaian (dapat diganti) dengan syarat bahwa pihak yang belakangan ini akan mengembalikan sejumlah yang sama dari macam dan keadaan yang sama pula (Pasal $1754 \mathrm{KUH}$ Perdata). ${ }^{107}$

Perjanjian Pinjam Meminjam merupakan perjanjian riil atau kontrak riil, oleh karena di dalam definisinya tidak disebutkan bahwa pihak kesatu mengikatkan diri untuk menyerahkan uang atau barang, melainkan ia memberikan kepada pihak yang lain suatu jumlah uang atau barangbarang. ${ }^{108}$

Yang dimaksud dengan perjanjian riil adalah perjanjian yang baru lahir, apabila benda (zaak) yang menjadi objek perjanjian diserahkan (levering), misalnya perjanjian pinjam pakau atau perjanjian penitipan, keharusan menyerahkan benda yang menjadi objek perjanjian merupakan syarat mutlak disamping kata sepakat. ${ }^{109}$ Oleh karena itu, biarpun A dan B sudah SEPAKAT sebulan yang lalu bahwa B boleh MEMINJAM mesin ketik milik A untuk pengetikan makalahnya, SELAMA mesin ketik tersebut BELUM DISERAHKAN secara FISIK oleh A kepada B, Perjanjian Pinjam Pakai TIDAK ADA, kata SEPAKAT saja TIDAK CUKUP disini. ${ }^{110}$

Konsekuensi hukum perjanjian pinjam meminjam merupakan dan

${ }^{107}$ Gunawan Sidauruk, Tanya Jawab Hukum Perdata Tentang Perjanjian Bernama, Cet. 1, (Bandung: Armico, 1981), hlm. 179.

${ }^{108}$ Ibid.

${ }^{109}$ Fred B.G. Tumbuan, Himpunan Kajian Mengenai Beberapa Produk Legislasi Dan Masalah Di Bidang Hukum Perdata, Cet. 1, (Jakarta: PT Gramedia Pustaka Utama, 2017), hlm. 5-6.

${ }^{110} \mathrm{Ibid}$. 
sebagai perjanjian riil adalah sebagai berikut: ${ }^{111}$

Pertama persetujuan peminjaman barang atau uang baru mengikat setelah barang atau uang yang diserahkan itu diterima oleh peminjam.

Kedua uang atau barang yang diterima oleh peminjam tersebut langsung menjadi miliknya si peminjam, sehingga bila hilang atau musnah menjadi tanggungannya si peminjam (vide Pasal $1755 \mathrm{KUH}$ Perdata).

Perbedaan antara pinjam meminjam dengan pinjam pakai antara lain sebagai berikut: ${ }^{112}$

\begin{tabular}{|c|c|c|}
\hline Karakteristik & Pinjam Pakai & $\begin{array}{c}\text { Pinjam } \\
\text { Meminjam }\end{array}$ \\
\hline $\begin{array}{l}\text { 1. Status / } \\
\text { kondisi } \\
\text { barang } \\
\text { Pinjaman }\end{array}$ & $\begin{array}{l}\text { - barangnya } \\
\text { TIDAK HABIS } \\
\text { karena } \\
\text { PEMAKAIAN }\end{array}$ & $\begin{array}{l}\text { - } \text { barangnya } \\
\text { HABIS karena } \\
\text { PEMAKAIAN }\end{array}$ \\
\hline $\begin{array}{l}\text { 2. Status } \\
\text { kepemilika } \\
\text { n barang } \\
\text { Pinjaman }\end{array}$ & $\begin{array}{l}\text { - barang TIDAK } \\
\text { menjadi } \\
\text { MILIKnya si } \\
\text { Peminjam }\end{array}$ & $\begin{array}{l}\text { - barang menjadi } \\
\text { MILIKnya si } \\
\text { Peminjam }\end{array}$ \\
\hline
\end{tabular}

Kewajiban dari orang yang meminjamkan uang (kreditor) adalah sebagai berikut: ${ }^{113}$

1) tidak boleh meminta pembayaran kembali sebelulum lewatnya waktu yang ditentukan dalam Perjanjian (Pasal 1759 KUH Perdata)

2) jika tidak telah ditetapkan sesuatu waktu untuk membayar kembali, dan untujk pembayaran kembali ini diminta oleh yang meminjamkan, maka Hakim mengingat KEADAAN dapat memberi tempo yang pantas untuk membayar kembali itu (Pasal 1760 KUH Perdata)

3) jika telah didtetapkan dalam Perjanjian bahwa si Peminjam akan

${ }^{111}$ Gunawan Sidauruk, Op.Cit. Lihat juga M. Yahya Harahap (a), Segi-Segi Hukum Perjanjian, Cet. 2, (Bandung: PT. Alumni, 1986), hlm. 298.

${ }^{112}$ Gunawan Sidauruk, Loc.Cit, hlm. 61-62

${ }^{113} \mathrm{Ibid}, \mathrm{hlm} .62$ mengembalikan Uang atau

barangnya apabila ia mampu membayarnya, maka Hakim dapat menentukan waktu pembayarannya dengan mengingat KEADAAN (Pasal 1761 KUH Perdata)

4) bila yang dipinjamkan itu barang (beras, gandum, dll) yang dapat menimbulkan kerugian pada yang meminjam, orang yang meminjamkan hatus menanggung akibat kerugian itu (Pasal 1762 KUH Perdata)

Sedangkan kewajiban dari Debitur (Si Peminjam) uang adalah sebagai berikut: ${ }^{114}$

1) mengembalikan uang atau barang yang dipinjamkanya dalam jumlah dan keadaan yang sama

2) jika si Peminjam tidak mampu membayar dalam jumlah dan keadaan yang sama, maka ia diwajibkan membayar harganya, dalam hal mana harus diperhatikan waktu dan tempatnya barang-barang harus dikembalikan. Jika waktu dan tempat ini tidak telah ditetapkan, maka harus dilihat pada waktu dan tempat dimana Perjanjian telah terjadi.

Saat pengembalian Uang yang dipinjam oleh si Peminjam (debitor) ada 2 (dua) keadaan yang harus diperharikan, sebagai berikut: ${ }^{115}$

Pertama jika dalam perjanjian ada ditentukan batas waktunya, maka 1) harus dikembalikan tepat pada batas waktu yang diperjanjikan oleh si peminjam; 2) pihak yang meminjamkan tidak boleh meminta pengembalian barang/uang sebelum sampai pada batas waktu yang diperjanjikan itu (Pasal 1759 KUH Perdata).

${ }^{114}$ Ibid, hlm. 62-63

${ }^{115}$ M. Yahya Harahap (a), Op.Cit, hlm. 301- 
Kedua apabila jangka waktunya tidak ditentukan dalam perjanjian 1) pihak yang meminjam boleh meminta pengembalian serta dapat dikembalikan oleh si peminjam dengan sukarela; 2) apabila permintaan pengembalian dilakukan pihak yang meminjamlan melalui proses peradilan, hakim harus memberi suatu waktu pertangguhan, setelah mempertimbangkan hal ikhwal yang bersangkutan dengan waktu pertangguhan tersebut.

B. Keabsahan Pinjam Meminjam Uang Secara Lisan

Perjanjian pinjam meminjam uang merupakan bentuk khusus dari perjanjian pinjam meminjam yang diatur dalam bab XIII pinjam meminjam, terdiri dari 16 (enam belas) Pasal (Pasal 1754 sampai dengan Pasal 1769) bersifat mengatur (aanvullendrecht), dan tidak norma yang mengharuskannya dibuat secara tertulis, sehingga suatu perjanjian pinjam meminjam uang dapat dibuat secara lisan ataupun tertulis baik akta/surat dibawah tangan maupun akta otentik.

Apabila pembuatan perjanjian pinjam meminjam uang dibuat secara tertulis baik akta/surat dibawah tangan maupun akta otentik adalah untuk mempermudah dan memperkuat pembuktian sebagaimana diatur dalam buku IV KUH Perdata yaitu tentang pembuktian dan daluwarsa, bukan untuk menentukan kebsahan suatu perjanjian pinjam meminjam uang, melainkan untuk pembuktian.

Untuk menilai keabsahan suatu perjanjian pinjam meminjam uang secara lisan dapat dilakukan 3 (tiga) pendekatan yaitu:

Pertama ditinjau dari aspek adanya kesepakatan sebagaimana dimaksud dalam Pasal 1320 KUH Perdata yang dicapai atau diperoleh bukan dan tidak karena paksaan (dwang), kekhilafan (dwaling) dan penipuan (bedrog) (vide Pasal 1320 Jis. Pasal 1321 sampai dengan Pasal 1328 KUH Perdata).

Kedua ditinjau dari aspek adanya sebab yang halal sebagaimana dimaksud dalam Pasal 1320 Jo. Pasal 1337 KUH Perdata. Perjanjian / persetujuan pinjam meminjam uang secara lisan, dengan objek pinjam meminjam uang adalah berupa uang tunai dalam jumlah tertentu yang telah disepakati, sasaran / tujuan atau alasan yang diperbolehkan oleh hukum itu merupakan tujuan bersama (gezaameenlijk doel) yang hendak dicapai para pihak sebagai dasar diadakannya pinjam meminjam uang secara lisan tersebut, serta persetujuan / perjanjian pinjam meminjam uang secara lisan tersebut tidak bertentangan dengan kesusilaan yang baik maupun tidak bertentangan dengan ketertiban umum.

Ketiga ditinjau dari aspek perjanjian pinjam meminjam sebagaimana dimaksud dalam Pasal 1755 Jo. Pasal 1754 KUH Perdata. Suatu perjanjian pinjam meminjam uang secara lisan adalah sah dan berharga menurut hukum, apabila didahului adanya pernyataan kehendak dan persesuaian kehendak pihak yang meminjamkan uang (Kreditur) dan pihak yang meminjam/si Peminjam/Debitur. (vide Pasal 1338 Jo. Pasal 1320 Jis. Pasal 1755 dan Pasal 1754 KUH Perdata). Perjanjian / persetujuan pinjam meminjam uang secara lisan telah terjadi, apabila pihak yang meminjamkan telah menyerahkan uang yang dipinjam tersebut dan pihak yang meminjam telah menerima uang yang dimaksudkan tersebut (vide Pasal 1755 Jo. Pasal 1754 KUH Perdata).

\section{Penutup}

A. Kesimpulan

Setelah menguraikan, mengkaji dan menganalisis pengaturan hukum 
pinjam meminjam uang secara lisan, maka dapat disimpulkan sebagai berikut:

Pertama perjanjian pinjam meminjam uang merupakan bentuk khusus dari perjanjian pinjam meminjam yang diatur dalam bab XII pinjam meminjam KUH Perdata, terdiri dari 16 (enam belas) Pasal (Pasal 1754 sampai dengan Pasal 1769) bersifat mengatur (aanvullendrecht), dan tidak norma yang mengharuskannya dibuat secara tertulis.

Kedua, suatu perjanjian pinjam meminjam uang secara lisan adalah sah dan berharga serta memiliki kekuatan hukum yang mengikat menurut hukum, apabila didahului adanya pernyataan kehendak dan persesuaian kehendak antara pihak yang meminjamkan uang dan pihak yang meminjam/si peminjam. (vide Pasal 1338 Jo. Pasal 1320 Jo. Pasal 1337 Jis. Pasal 1755 dan Pasal 1754 KUH Perdata), serta apabila:

1) pinjam meminjam uang tersebut tidak bertentangan dengan Undang Undang.

2) pinjam meminjam uang tersebut bukan dan tidak merupakan tindakan yang dilarang oleh Undang - Undang.

3) pinjam meminjam uang tersebut tidak bertentangan dengan kesusilaan yang baik.

4) pinjam meminjam uang tersebut tidak bertentangan dengan ketertiban umum.

B. Rekomendasi

Berdasarkan kesimpulan yang telah dirumuskan di atas, maka dapat disarankan sebagai berikut:

Pertama perlu adanya UndangUndang tentang Perikatan yang mengatur jenis atau macam, bentuk, syarat sah suatu perjanjian termasuk di dalamnya mengatur hal-hal berkaitan tentang pinjam meminjam uang.

Kedua perlu dilakukan sinkronisasi dan harmonisasi antara rancangan Undang-Undang Tentang Perikatan dengan rancangan Undang-Undang hukum acara perdata, termasuk di dalamnya mengatur berkaitan tentang pembuktian pinjam meminjam uang.

\section{DAFTAR PUSTAKA}

Buku-buku:

Amirudin dan Zainal Asikin, Pengantar Metode Penelitian Hukum, Ed. 1, Cet. 3, Jakarta, PT Raja Grafindo Persada, 2006

Badrulzaman, Mariam Darus, et.al. Kompilasi Hukum Perikatan, Cet. 1, Bandung: PT Citra Aditya Bakti, 2000.

Badrulzaman, Mariam Darus KUH Perdata Buku III: Hukum Perikatan Dengan Penjelasan, Ed. 2, Cet. 3, Bandung: Alumni, 2011.

Budiono, Herlien, (a). Asas Keseimbangan Bagi Hukum Perjanjian Indonesia (Hukum Perjanjian Berdasarkan Asasasas Wigati Indonesia), Cet. 1, Bandung: PT Citra Aditya Bakti, 2006.

(b). Ajaran Umum Hukum Perjanjian Dan Penerapannya Di Bidang Kenotariatan, Cet. 1, Bandung: PT Citra Aditya Bakti, 2009.

Creswell, John W. Research Design of Qualitative \& Quantitative Approches, dalam Natasya Yunita Sugiastuti, Tradisi Hukum Cina: Negara Dan Masyarakat (Studi Mengenai Peristiwaperistiwa Hukum di Pulau Jawa Zaman Kolonial (1870-1942), Cet. 1, Jakarta, Program Pasca Sarjana Fakultas Hukum Universitas Indonesia, 2003.

Daeng Naja, H.R. Teknik Pembuatan Akta (Buku Wajib Kenotariatan), Cet. 1, Yogyakarta: Pustaka Yustisia, 2012. 
Denzin, Norman K. \& Yvona S. Lincoln, ed. Handbook of Qualitative Research dikutip dari Natasya Yunita Sugiastuti, Tradisi Hukum Cina: Negara Dan Masyarakat (Studi Mengenai Peristiwa-peristiwa Hukum di Pulau Jawa Zaman Kolonial (18701942), Cet. 1, Jakarta, Program Pasca Sarjana Fakultas Hukum Universitas Indonesia, 2003.

Erwin, Muhamad. dan H. Firman Freddy Busroh, Pengantar Ilmu Hukum, Cet. 1, Bandung: PT Refika Aditama, 2012.

Harahap, M. Yahya (a). Segi-Segi Hukum Perjanjian, Cet. 2, Bandung : PT. Alumni, 1986.

(b). Hukum Acara Perdata: Gugatan, Persidangan, Penyitaan, Pembuktian, dan Putusan Pengadilan, Ed. 2, Cet. 1, Jakarta: Sinar Grafika, 2017.

Ibrahim, Jhonny. Teori Dan Metodologi Penelitian Hukum Normatif, Ed. Revisi, Cet.3., Malang, Bayumedia Publishing, 2007

Khairandy, Ridwan. Hukum Kontrak Indonesia dalam Perspektif Perbandingan (Bagian Pertama), Cet. 1, Yogyakarta: FH UII Press, 2013.

Koentjaraningrat (Ed.), Metode-metode Penelitian Masyarakat, Cet. 9, Jakarta, PT. Gramedia Jakarta, 1989 Kusumaatmadja, Mochtar. dan B. Arief Sidharta, Pengantar Ilmu Hukum Buku I : Suatu Pengenalan Pertama Ruang Lingkup Berlakunya Ilmu Hukum, Bandung: Alumni, 2000.

Lumban Tobing, G.H.S. Peraturan Jabatan Notaris Di Indonesia, Jakarta: PT Erlangga, 1980.

Machmudin, Dudu Duswara, Pengantar Ilmu Hukum: Sebuah Sketsa, Bandung: Refika Aditama, 2001. Mamudji, Sri. Et.al, Metode Penelitian Dan Penulisan Hukum, Cet. 1, Depok, Badan Penerbit FH UI, 2005
Marzuki, Peter Mahmud, Penelitian Hukum, Ed. Revisi, Cet. 8, Jakarta, Kencana, Prenada Media Grup, 2013

Mertokusumo, Sudikno (a). Mengenal Hukum Suatu Pengantar, Cet. 2, Yogyakarta: Liberty, 1999.

(b). Hukum Acara Perdata Indonesia, Ed. 6, Yogyakarta: Liberty, 2002.

Muhammad, Abdulkadir. Hukum dan Penelitian Hukum, Cet. 1, Bandung, PT. Citra Aditya Bakti, 2004

Muljadi, Kartini. dan Gunawan Wijaya. Perikatan Yang Lahir Dari Perjanjian, Cet. 6, Jakarta: PT Rajagrafindo Persada, 2014.

Purbacaraka, Purnadi dan Soerjono Soekanto, Sendi-sendi Ilmu Hukum Dan Tata Hukum, Bandung: PT Alumni, 1979.

Purwahid Patrik, Dasar-Dasar Hukum Perikatan (Perikatan Yang Lahir Dari Perjanjian Dan Undang-Undang), Cet. 1, Bandung: CV Mandar Maju, 1994

Satrio, J. (a). Hukum Perikatan: Perikatan Yang Lahir Dari Perjanjian Buku I, Cet. 1, Bandung: PT Citra Aditya Bakti, 1995.

(b). Hukum Perikatan: Perikatan Yang Lahir Dari Perjanjian Buku II, Cet. 1, Bandung: PT Citra Adity Bakti, 1995.

Sidauruk, Gunawan. Tanya Jawab Hukum Perdata Tentang Perjanjian Bernama, Cet. 1, (Bandung : Armico, 1981), hlm. 179.

Sjahdeini, Sutan Remy. Kebebasan Berkontrak Dan Perlindungan Yang Seimbang Bagi Para Pihak Dalam Perjanjian Kredit Bank Di Indoensia, Cet. 1, Jakarta: Institut Bankir Indonesia, 1993.

Soekanto, Soerjono. dan Sri Mamudji, Penelitian Hukum Normatif Suatu Tinjauan Singkat, Ed. 1, Cet. 5, Jakarta, PT. RajaGrafindo Persada, 2001 
Soemitro, Ronny Hanitijo. Metodologi Penelitian Hukum Dan Jurimetri, Cet. ke-3, Jakarta, Ghalia Indonesia, 1988

Subagyo, Joko. Metode Penelitian Dalam Teori Dan Praktek, Jakarta, Rineka Cipta, 2004

Sunarjati Hartono, C. F. G. Penelitian Hukum Di Indonesia Pada Akhir Abad $\mathrm{Ke}-20$, Cet. 1, Bandung, Alumni, 1994

Sugiastuti, Natasya Yunita. Tradisi Hukum Cina: Negara Dan Masyarakat (Studi Mengenai Peristiwa-peristiwa Hukum di Pulau Jawa Zaman Kolonial (18701942), Cet. 1, Jakarta, Program Pasca Sarjana Fakultas Hukum Universitas Indonesia, 2003.

Sunggono, Bambang. Metodologi Penelitian Hukum (Suatu Pengantar), Ed. 1., Cet. 3, Jakarta, PT. Raja Grafindo Persada, 2001.

Surakhmad, Winarno. Pengantar Penelitian Ilmiah, Dasar Metode dan Teknik, Ed. 7, Bandung, Tarsito, 1984

Subekti, R. (a). Hukum Perjanjian, Cet. 23, Jakarta: Intermasa, 2010.

(b). Hukum Pembuktian, Cet. 8, Jakarta: Penerbit Pradnya Paramita, 1987.

Suryodiningrat, R. M. Azas-Azas Hukum Perikatan, Ed. 2, Bandung: Tarsito, 1985.

Syaifuddin, Muhammad. Hukum Kontrak: Memahami Kontrak Dalam Perspektif Filsafat, Teori, Dogmatik, Dan Praktik Hukum (Seri Pengayaan Hukum Perikatan), Cet. 1, Bandung: PT Mandar Maju, 2012.

Tresna, Mr R. Komentar HIR, Cet. 18, Jakarta: PT Pradnya Paramita, 2005.

Tumbuan, Fred B.G. Himpunan Kajian Mengenai Beberapa Produk Legislasi Dan Masalah Di Bidang Hukum Perdata, Cet. 1, Jakarta: PT Gramedia Pustaka Utama, 2017.
Waluyo, Bambang. Penelitian Hukum Dalam Praktek, Ed. 1, Cet. 2, Jakarta: Sinar Grafika, 1996

Widjaya, I.G. Rai. Merancang Suatu Kontrak (Contract drafting) Teori Dan Praktek, Ed. Revisi, Jakarta: Kesaint Blanck, 2003

Wignjodipoero, Soerojo. Pengantar Ilmu Hukum, Jakarta: CV. Haji Masagung, 1989.

Perundang-undangan:

Subekti, R. dan R. Tjitrosudibio, Kitab Undang-Undang Hukum Perdata, diterjemahkan dari Burgelijk Wetboek, Cet. 41, Jakarta: Balai Pustaka, 2014.

HIR (Het Herziene Indonesisch Reglement ; Reglemen Indonesia Yang Diperbaharui), dimuat dalam Staatsblad 1941 Nomor 44.

RBg (Rechtsreglement Buitengewesten ; Reglemen Acara Untuk Daerah Luar Jawa dan Madura), dimuat dalam Staatsblad tahun 1927 Nomor 227.

$\mathrm{RR}$ (Reglement op de Rechtsvordering ; Reglemen Acara Perdata), dimuat dalam Staatsblad tahun 1847 Nomor 52.

Indonesia, Undang-Undang Tentang Jabatan Notaris, UU No. 30 Tahun 2004, Lembaran Negara Republik Indonesia Tahun 2004 Nomor 117, Tambahan Lembaran Negara Republik Indonesia Nomor 4432.

------, Undang-Undang Tentang Perumahan Dan Kawasan Pemukiman, UU No. 1 Tahun 2011, Lembaran Negara Republik Indonesia Tahun 2011 Nomor 7, Tambahan Lembaran Negara Republik Indonesia Nomor 5188.

------, Undang-Undang Tentang Perubahan Atas Undang-Undang Nomor 30 Tahun 2004 Tentang Jabatan Notaris, UU No. 2 Tahun 2014, Lembaran 
Keabsahan Pinjam Meminjam Uang Secara Lisan Dalam

Perspektif Hukum Perdata

Negara Republik Indonesia Tahun

2014 Nomor 3.

Indonesia, Peraturan Pemerintah Tentang

Penghunian Rumah Oleh Bukan

Pemilik, PP No. 44 Tahun 1994,

Lembaran Negara Republik

Indonesia Tahun 1994 Nomor 73,

Tambahan Lembaran Negara

Republik Indonesia Nomor 3576. 